\title{
Hox gene expression during development of the phoronid Phoronopsis harmeri
}

\author{
Ludwik Gąsiorowski ${ }^{1,2}$ and Andreas Hejnol ${ }^{1,2^{*}}$ (D)
}

\begin{abstract}
Background: Phoronida is a small group of marine worm-like suspension feeders, which together with brachiopods and bryozoans form the clade Lophophorata. Although their development is well studied on the morphological level, data regarding gene expression during this process are scarce and restricted to the analysis of relatively few transcription factors. Here, we present a description of the expression patterns of Hox genes during the embryonic and larval development of the phoronid Phoronopsis harmeri.

Results: We identified sequences of eight Hox genes in the transcriptome of Ph. harmeri and determined their expression pattern during embryonic and larval development using whole mount in situ hybridization. We found that none of the Hox genes is expressed during embryonic development. Instead their expression is initiated in the later developmental stages, when the larval body is already formed. In the investigated initial larval stages the Hox genes are expressed in the non-collinear manner in the posterior body of the larvae: in the telotroch and the structures that represent rudiments of the adult worm. Additionally, we found that certain head-specific transcription factors are expressed in the oral hood, apical organ, preoral coelom, digestive system and developing larval tentacles, anterior to the Hox-expressing territories.

Conclusions: The lack of Hox gene expression during early development of Ph. harmeri indicates that the larval body develops without positional information from the Hox patterning system. Such phenomenon might be a consequence of the evolutionary intercalation of the larval form into an ancestral life cycle of phoronids. The observed Hox gene expression can also be a consequence of the actinotrocha representing a "head larva", which is composed of the most anterior body region that is devoid of Hox gene expression. Such interpretation is further supported by the expression of head-specific transcription factors. This implies that the Hox patterning system is used for the positional information of the trunk rudiments and is, therefore, delayed to the later larval stages. We propose that a new body form was intercalated to the phoronid life cycle by precocious development of the anterior structures or by delayed development of the trunk rudiment in the ancestral phoronid larva.
\end{abstract}

Keywords: Lophophorata, Spiralia, Biphasic life cycle, Intercalation, Life history evolution, Body plan, Indirect development, Lox2, Head, Brain

*Correspondence: andreas.hejnol@uib.no

1 Sars International Centre for Marine Molecular Biology, University of Bergen, Thormøhlensgate 55, 5006 Bergen, Norway

Full list of author information is available at the end of the article

\section{Background}

Hox genes encode a family of transcription factors present in Bilateria and Cnidaria [1-4], which bind with their conserved homeodomain directly to regulatory regions of downstream genes and activate or suppress their expression (e.g. [5-7]). In many clades, Hox genes are differentially expressed in the early developmental stages along the anterior-posterior axis of the developing embryo,

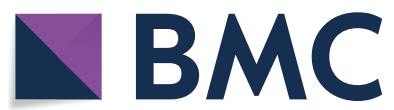

(c) The Author(s) 2020. This article is licensed under a Creative Commons Attribution 4.0 International License, which permits use, sharing, adaptation, distribution and reproduction in any medium or format, as long as you give appropriate credit to the original author(s) and the source, provide a link to the Creative Commons licence, and indicate if changes were made. The images or other third party material in this article are included in the article's Creative Commons licence, unless indicated otherwise in a credit line to the material. If material is not included in the article's Creative Commons licence and your intended use is not permitted by statutory regulation or exceeds the permitted use, you will need to obtain permission directly from the copyright holder. To view a copy of this licence, visit http://creativeco mmons.org/licenses/by/4.0/. The Creative Commons Public Domain Dedication waiver (http://creativecommons.org/publicdomain/ zero/1.0/) applies to the data made available in this article, unless otherwise stated in a credit line to the data. 
being one of the important components of molecular patterning of axial identities [4-6, 8-10]. The diversity of Hox genes present in extant Bilateria originated likely by multiple duplication events, which resulted in the physical linkage of Hox genes in the genomes of many Bilateria, the so-called Hox clusters (e.g. [9, 11, 12]. It is possible to discriminate organized, split and disorganized Hox clusters, depending on the level of their organization $[7,12]$ and in certain Bilateria the Hox genes are expressed in roughly the same order as they are located in the cluster: a phenomenon referred to as collinearity $[6,9,11]$. The correspondence between position of the gene in the cluster and onset of its expression might have a temporal (during development) or spatial (along body axis) character and accordingly it is possible to discriminate between the temporal and spatial collinearity. It has been proposed that collinearity, especially the temporal one, is a major factor responsible for conservation (or maybe even formation) of the ordered Hox cluster in the genome $[9,11-16]$.

Although expression of Hox genes has been described during embryonic and larval development of many animals representing diverse evolutionary lineages [4, 16-49], there are still some clades for which information about Hox expression during development is lacking. Among them are phoronids, marine, sessile worms, which feed using a specialized filter apparatus, the socalled lophophore ( $l p$ in Fig. 1a). Due to the presence of lophophore, Phoronida have been traditionally united with two other clades-Ectoprocta (Bryozoa) and Brachiopoda-into the group called Lophophorata [50, 51], which recently gained support as a valid clade from several transcriptomic and phylogenomic studies [52-55]. Although originally the Lophophorata were considered as deuterostomes [50,51], molecular data showed their protostome affinity [56] and currently the lophophorates

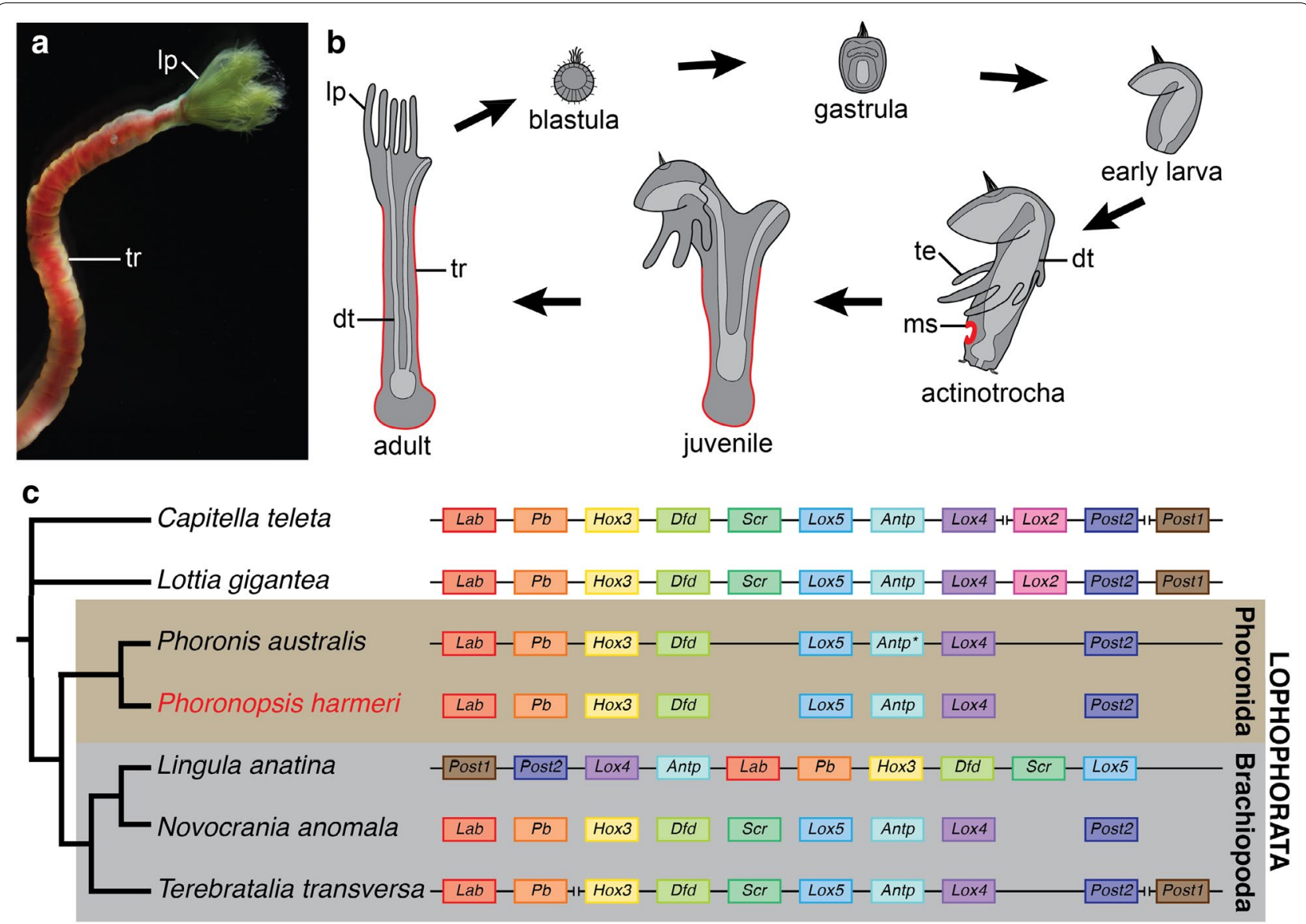

Fig. 1 Phoronopsis harmeri: morphology of the anterior part of living animal (a) and scheme of its life cycle (b). Hox clusters organization and Hox genes complement in various Spiralia (c), based on $[16,89,107]$. Metasomal sac and adult trunk originating from it are marked in red in $\mathbf{b}$. Gene antp from Phoronis australis (marked with asterisk) was originally described as lox2 (see text for discussion). For Phoronopsis harmeri and Novocrania anomala only the Hox complement is available (data on cluster organization are missing). The vertical bars in C indicate boundaries of the particular scaffolds of the split Hox clusters. Abbreviations: dt digestive tract, Ip lophophore, ms metasomal sac, te larval tentacles, tr adult trunk 
occupy a well-supported position within the clade of Spiralia [52-55, 57]. Most phoronids develop through a distinctive planktotrophic larval stage, called actinotrocha [58-61]. After a prolonged planktonic life, the actinotrocha larva settles and undergoes drastic metamorphosis (Fig. 1b), during which the rudiment of the body wall of the adult worm, the so-called metasomal sac (ms, Fig. 1b), is everted and the rudiments of the adult internal organs descent from the larval body to the newly formed juvenile worm (Fig. 1b) [60, 61]. The only exception from this pattern is Phoronis ovalis, which is a sister group to the remaining phoronids [62-64] and which develops through the creeping slug-like larva [60]. After a few days of development the active larva of $P$. ovalis settles and acquires a smooth hemispherical shape [60]. Unfortunately, the degree of the metamorphosis-related remodeling of internal structures in $P$. ovalis remains poorly examined.

The phoronid development has been well studied on the morphological level (e.g. [58-61, 65-85]), including preliminary cell lineage, blastomere ablation and fate mapping studies [86-88]. However, information about the molecular patterning is limited to the single study of nine transcription factors (which include anterior, posterior and endomesodermal markers) during the development of Phoronopsis harmeri [85]. Importantly, information about expression of Hox genes during development of any phoronid species is still lacking $[40,59]$.

Recently, Luo et al. have demonstrated that in phoronid Phoronis australis a Hox cluster is highly organized with all of the eight phoronid Hox genes forming a single cluster that retains the ancestral spiralian order of genes ([89], also Fig. 1c). This is in contrast to brachiopods, the putative close relatives of Phoronida, where various level of Hox cluster disorganization was shown (Fig. 1c) and temporal and spatial collinearity is missing $[16,40,89$, 90]. Therefore, it remains important to examine whether phoronid Hox genes are also expressed in the spatiotemporally collinear manner during development, which would correspond with the retention of the organized Hox cluster shown in this clade.

Phoronids exhibit a biphasic life cycle with planktotrophic larvae that transform into the juvenile in a catastrophic metamorphosis event (Fig. 1b; e.g. [59, 60, 73, $75,81,82])$, which is much more drastic than relatively gradual metamorphosis of most Spiralia. Importantly, the A-P axis of the larva is profoundly altered during metamorphosis $[60,77,81,82]$ and results in the U-shaped organization of the internal structures of the juvenile worm (Fig. 1b). In animals with pronounced metamorphosis Hox genes might exhibit noticeable differences in the expression patterns during development of larval and adult bodies. In pilidiophoran nemerteans and indirectly developing hemichordates it has been demonstrated that Hox genes are involved in patterning of only adult bodies $[37,38]$, while in tunicates and sea urchins different sets of Hox genes are expressed during larval and adult body development $[21,22,44,47]$. On the other hand, in animals with non-catastrophic metamorphosis (e.g. cephalochordates, mollusks, annelids or brachiopods), the Hox genes seem to pattern both the larval and adult body plans in a relatively similar way $[31,39,40,46,48]$. However, studies focusing on metamorphosis-related differences of Hox gene expression in Bilateria are still limited to a relatively few evolutionary lineages $[40,91]$. Therefore, the comparison of Hox gene expression between the embryonic and larval development and the development of the metasomal sac in phoronids might shed new light into the understanding of the evolution of differential genetic control of the axis patterning in animals with extreme metamorphosis.

In this study, we investigated the Hox genes complement and their expression patterns during the development of the phoronid Phoronopsis harmeri, for which the extensive data on the morphological aspects of the development and some molecular data on the A-P axis are available [66, 72, 75-78, 80-82, 84, 85]). Our aim was to answer whether phoronid Hox genes show staggered expression along the A-P axis at any of the developmental stages as well as to examine if there are traces of temporal collinearity that could hint to the presence of a Hox cluster as described for another phoronid P. australis [89]. We also wanted to investigate whether there are differences in the Hox gene expression (and possibly in the patterning of the A-P axes) between the larva and the rudiment of the forming juvenile worm and compare our findings with other species that exhibit extreme metamorphosis.

\section{Results}

\section{Hox complement and gene orthology}

We identified eight Hox genes in the transcriptome of Ph. harmeri and our phylogenetic analysis allowed their assignment to particular orthology groups (Fig. 2). Those genes represent orthologues of the genes labial (lab), proboscipedia $(p b)$, hox3, deformed (dfd), lox5, antennapedia (antp), lox4 and post2 (Figs. 1c and 2). Moreover, in addition to the paraHox gene $c d x$ reported by Andrikou et al. [85], we identified two other paraHox genes in the transcriptome of Ph. harmeri-gsx and $x$ lox. Most of the Hox orthologues form distinct clades in our phylogenetic tree (Fig. 2). Sequences from the three orthologues ( $p b$, sex combs reduced (scr) and antp) do not form clades but rather grades of similar sequences (Fig. 2), which nevertheless allow the exact orthology assessment. We found that the gene identified by Luo et al. as lox 2 in the genome 


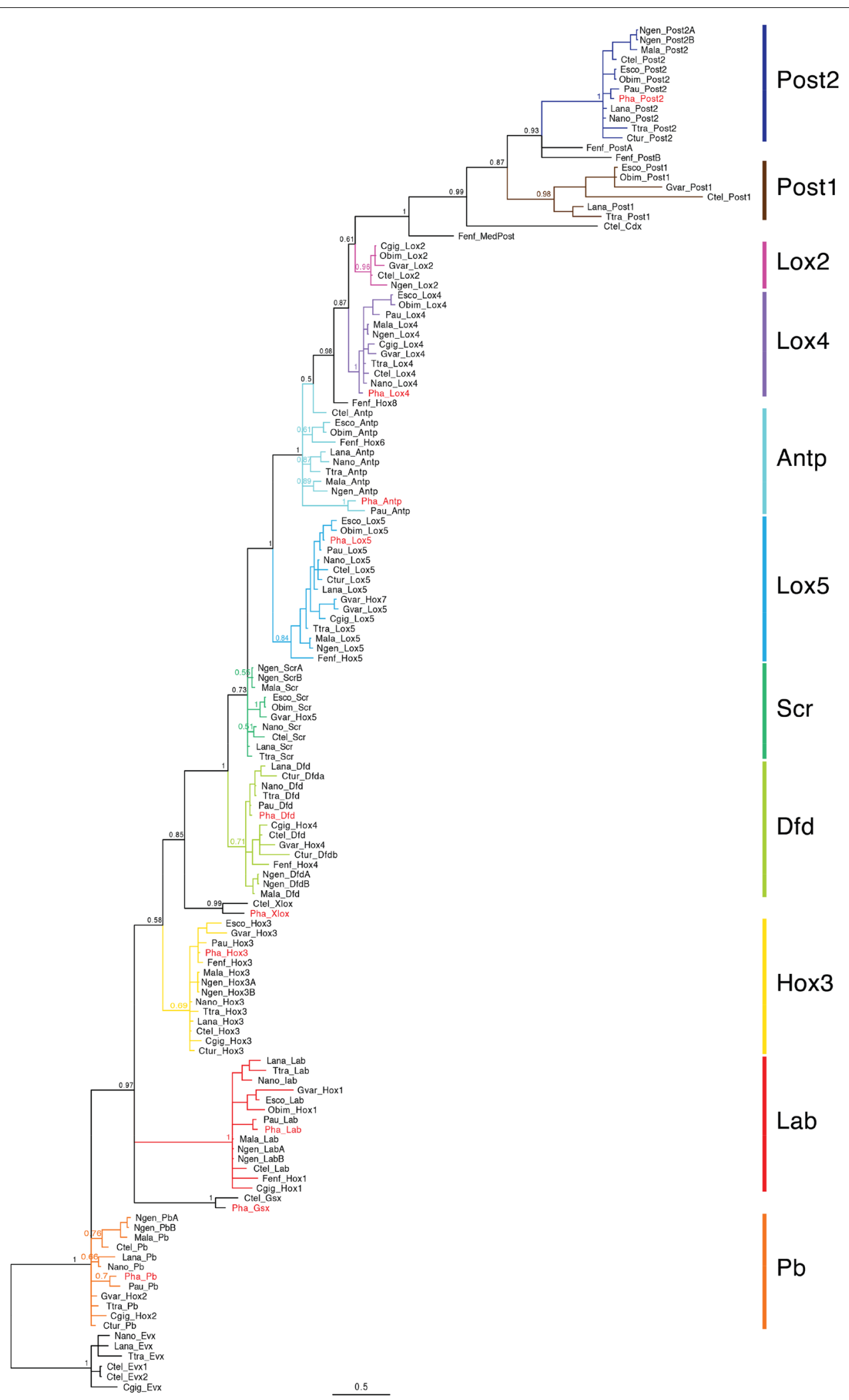

Fig. 2 Bayesian phylogeny under JTT + I+G substitution model of the amino acid sequences of spiralian Hox genes homeodomains, including phoronid sequences. Genes from Ph. harmeri are marked in red. Posterior probability values are shown for important clades. Full species names and sequences accession number are provided in Additional file 1: Table S1 
of P. australis [89] and its orthologue in Ph. harmeri do not fall into the clade containing lox2 sequences from other Spiralia, but instead they group in the grade containing antp sequences. Accordingly, sequence of those two phoronid genes lack most of the residues proposed as signature of lox 2 by de Rosa et al. (Additional file 1: Fig. S1; [92]).

\section{Embryonic and larval development of Ph. harmeri}

Embryos and larvae of Ph. harmeri are relatively transparent and many aspects of their morphology can be easily observed with the light microscope using Nomarski interference contrast (Fig. 3). At $9{ }^{\circ} \mathrm{C}$ the blastula stage is reached at about $6-8 \mathrm{~h}$ post-fertilization (hpf). Around $12 \mathrm{hpf}$ a swimming blastula with a large blastocoel $(b c)$ is formed (Fig. 3A, A'). At 20 hpf the gastrulation process is initiated, which leads to the formation of the gastrula (Fig. 3B, B') that displays a distinctive blastopore $(b p)$, the archenteron (ar) and the anterior mesoderm $(a m)$. Subsequently, the embryo (including the archenteron) elongates along the A-P axis and the oral hood (oh) develops anteriorly leading to the formation of the early larval stage, at approximately $40 \mathrm{hpf}$ (Fig. 3C, C'). In the posterior part of the early larva the proctodeum $(p d)$ develops, which merges with the posterior midgut $(m g)$, forming a larval digestive system. Ventrally to the proctodeum the first undifferentiated rudiment of the protonephridia is present ( $p r$ in Fig. $3 \mathrm{C}, \mathrm{C}^{\prime}$ ). At $60 \mathrm{hpf}$ the pre-tentacle larval stage is reached (Fig. 3D, D'), which possesses a through-gut (with esophagus, es; stomach, $s t$; midgut, $m g$; and proctodeum, $p d$ ), an apical organ (ao), protonephridial rudiments $(p r)$ and rudiments of the first

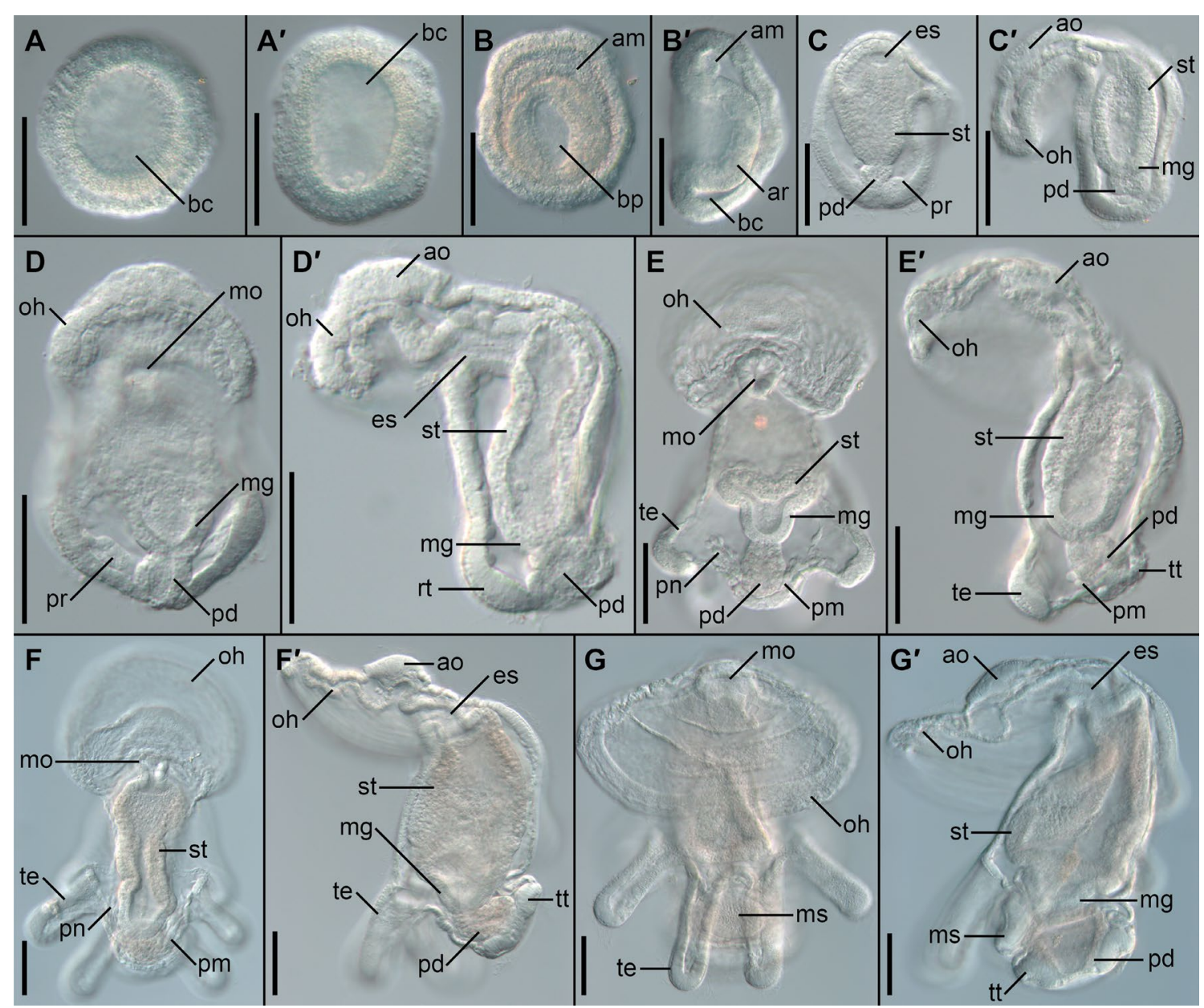

Fig. 3 Development of Phoronopsis harmeri. Blastula, $12 \mathrm{hpf}\left(\mathbf{A}, \mathbf{A}^{\prime}\right)$; gastrula, $24 \mathrm{hpf}\left(\mathbf{B}, \mathbf{B}^{\prime}\right)$; early larva, $42 \mathrm{hpf}\left(\mathbf{C}, \mathbf{C}^{\prime}\right)$; pre-tentacle larva, 56 hpf (D, $\left.\mathbf{D}^{\prime}\right)$; actinotrochae: $3 \mathrm{dpf}\left(\mathbf{E}, \mathbf{E}^{\prime}\right), 5 \mathrm{dpf}\left(\mathbf{F}, \mathbf{F}^{\prime}\right)$ and $7 \mathrm{dpf}\left(\mathbf{G}, \mathbf{G}^{\prime}\right)$. For each developmental stage the left panel shows embryo or larvae in dorso-ventral view and right panel (marked as') in lateral view with ventral to the left; anterior is to the top on all panels. Scalebars $50 \mu \mathrm{m}$. am anterior mesoderm, ao apical organ, ar archenteron wall, bc blastocoel, bp blastopore, es esophagus, mg midgut, mo mouth opening, ms metasomal sac, oh oral hood, pd proctodeum, $p m$ posterior mesoderm, $p n$ protonephridium, pr protonephridial rudiment, $r t$ tentacle rudiment, st stomach, te tentacle, $t t$ telotroch 
three pairs of tentacles $(r t)$. Three days post-fertilization (dpf) larvae can be already identified as early 6-tentacle actinotrocha (Fig. 3E, E') due to the presence of three pairs of well-defined tentacles $(t e)$. At this stage the larval protonephridia reach their definite branching form (pn, Fig. 3E), the rudiments of posterior mesoderm are morphologically distinguishable (pm, Fig. $3 \mathrm{E})$ and the posterior telotroch starts to form around the anal opening (tt, Fig. 3E'). At $5 \mathrm{dpf}$ (Fig. 3F, F') the telotroch is fully formed, while the posterior mesoderm forms rudiments of the posterior coelom compartment (metacoel). The actinotrocha reach the 8-tentacle stage at $7 \mathrm{dpf}$ (Fig. 3G, $\left.G^{\prime}\right)$. At this stage the post-tentacular region of the body (larval trunk) elongates and the metasomal sac, a rudiment of the body wall of the prospective adult worm, is formed (ms, Fig. 3G, G'). The metasomal sac at this stage appears as an ectodermal thickening located on the ventral side under tentacle bases.

The actinotrocha of $P$. harmeri develops further during a prolonged planktonic life (2 weeks up to few months). During this process subsequent pairs of tentacles are added on the dorsolateral sides, while metasomal sac extends, forming elongated structure on the ventral side of the larvae [76, 81, 82]. The actinotrocha of $P$. harmeri reaches metamorphosis competence at the 24-tentacle stage $[76,82]$. The morphological details of the embryonic and larval development of Ph. harmeri are well described elsewhere [66, 72, 75-78, 80-82, 84, 85], therefore we did not examined further the embryonic and larval morphology.

\section{Hox gene expression}

We did not detect expression of any of the Hox genes in blastula and gastrula stages (Additional file 1: Fig. S2), despite the fact that the expression of other genes, used as positive control, can be easily detected on those developmental stages (and was also reported elsewhere [85]). Additionally, the signal from the probes develops usually faster in embryos compared to larval stages. As we detected signal from all of our molecular probes on later larval stages (see below) we conclude that none of the Hox genes is expressed to a detectable degree before $42 \mathrm{hpf}$.

Expression of the anterior Hox gene lab is detected for the first time during development at the late 6-tentacle actinotrocha stage (Fig. 4A g, h). The gene is expressed in the ventro-posterior ectodermal domain, between the tentacle bases and the telotroch (black arrowhead, Fig. $4 \mathrm{~A} g$ and $\mathrm{h}$ ) and in the paired domains of the dorsolateral posterior mesoderm (red arrowheads, Fig. 4A $\mathrm{g}$ and $\mathrm{h}$ ). Both of the expression domains persist to the 8-tentacle actinotrocha stage (Fig. 4A i and j). At this developmental stage the ectodermal domain is part of the metasomal sac, where $l a b$ is expressed in the cells of the anterior and bottom portion of the sac (Fig. 5a, a').

The second anterior Hox gene, $p b$, is the earliest expressed among all Hox genes in Ph. harmeri as its expression can be already detected in the early larva stage (42 hpf) in some of the cells of the protonephridial rudiment (blue arrowheads, Fig. 4B a, b). This expression domain remains in the pre-tentacle stage ( $56 \mathrm{hpf}, 4 \mathrm{~B} \mathrm{c}, \mathrm{d}$ ) and early and late 6 -tentacle actinotrocha (Fig. $4 \mathrm{~B} \mathrm{e,} \mathrm{f).} \mathrm{In}$ late 6-tentacle actinotrochae the gene additionally labels a portion of the posterior mesoderm (red arrowheads, Fig. $4 \mathrm{~B} \mathrm{~g}, \mathrm{~h}$ ). In 8-tentacle actinotrochae $p b$ is expressed in larval protonephridia (blue arrowheads, Figs. 4B i, j; $5 \mathrm{~g}$ ) and in two mesodermal domains, surrounding the metasomal sac (red arrowheads, Figs. 4B i, j; 5g).

Hox3 expression is detected in the late 6-tentacle actinotrochae in an ectodermal domain between the tentacle bases and telotroch (black arrowhead, Fig. 4C g, h). At the 8-tentacle actinotrocha stage hox3 is uniformly and exclusively expressed in the ectodermal cells of the metasomal sac (black arrowheads, Figs. 4C i, j; 5b, b').

$D f d$ expression initiates only at the 8-tentacle actinotrocha stage (Fig. 4D i, j), where the gene is expressed in a small, more proximal portion of the developing metasomal sac (Fig. 5c, c').

Transcripts of the gene lox 5 are detected first in the early 6-tentacle actinotrocha in posterior cells of the developing telotroch (green arrowhead, Fig. 4E e, f). Later on, lox5 remains expressed in the telotroch, expanding its expression domain to the entire structure (green arrowheads, Fig. 4E g-j). Two additional expression domains of lox5 also appear: the metasomal sac rudiment (black arrowhead, Fig. 4E h), which later encompasses the entire metasomal sac (black arrowheads Fig. 4E $\mathrm{j}$ and inset between i and j; Fig. 5d, d'), and an asymmetric domain in the left ventro-lateral posterior mesoderm, located between metasomal sac, midgut and left body wall (red arrowheads Fig. 4i, j and inset between g, h; Fig. 5h, i).

Expression of antp is not detected until the 8-tentacle actinotrocha stage. Transcripts of the gene are found in ectodermal cells around the opening of the metasomal sac (black arrowheads, Fig. 4F i, j; Fig. 5e, e'), which in a dorso-ventral view look like a ring on the ventral body surface between the tentacles base and the telotroch (Fig. 4F i).

Similarly, lox4 expression is not detected until the 8-tentacle actinotrocha stage, where the gene exclusively labels the ring of the cells at the junction between midgut and proctodeum (magenta arrowheads, Figs. 4G i, j; 5j).

The only posterior Hox gene, post2, is expressed from the early 6 -tentacle actinotrocha $(3 \mathrm{dpf})$ in the telotroch (green arrowheads, Fig. 4H e, f), initially in the posterior portion of the organ but later on the expression domain 


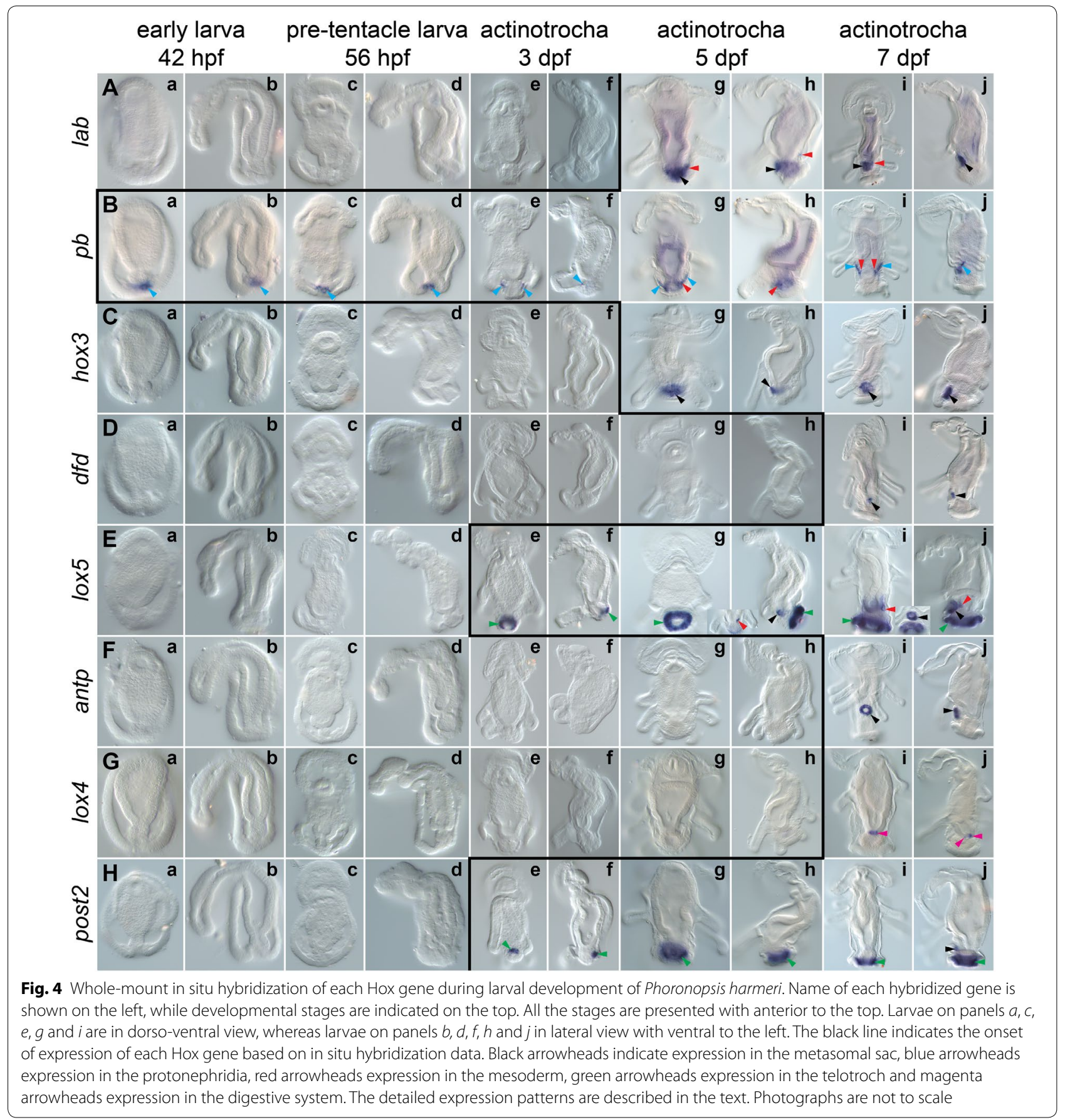

uniformly surrounds the anus (green arrowheads, Fig. $4 \mathrm{H}$ $\mathrm{g}-\mathrm{j}$ ). However, compared to lox 5 expression (which also demarcates the telotroch), post 2 labels only the inner ring of epidermal cells of the organ (compare Fig. $4 \mathrm{E}$ g-j, $\mathrm{H}$ $\mathrm{g}-\mathrm{j}$ ) and not the entire structure. At the 8-tentacle actinotrocha stage the gene post 2 is additionally expressed in the small posterior portion of the metasomal sac (black arrowhead, Figs. $\left.4 \mathrm{H} \mathrm{j}, 5 f, f^{\prime}\right)$.

\section{Head-specific genes}

In addition to the investigation of Hox genes we tested expression of several head-specific genes in the early larva (42 hpf) and advanced 8-tentacle actinotrocha. The genes, whose expression we investigated, were $f \circ x G$ (also known as brain factor-1 or BF-1), foxQ2, six3/6, otx and pax4/6, all commonly considered as head markers [38, 45, 89, 93-97]. One of the two fox $G$ paralogues 


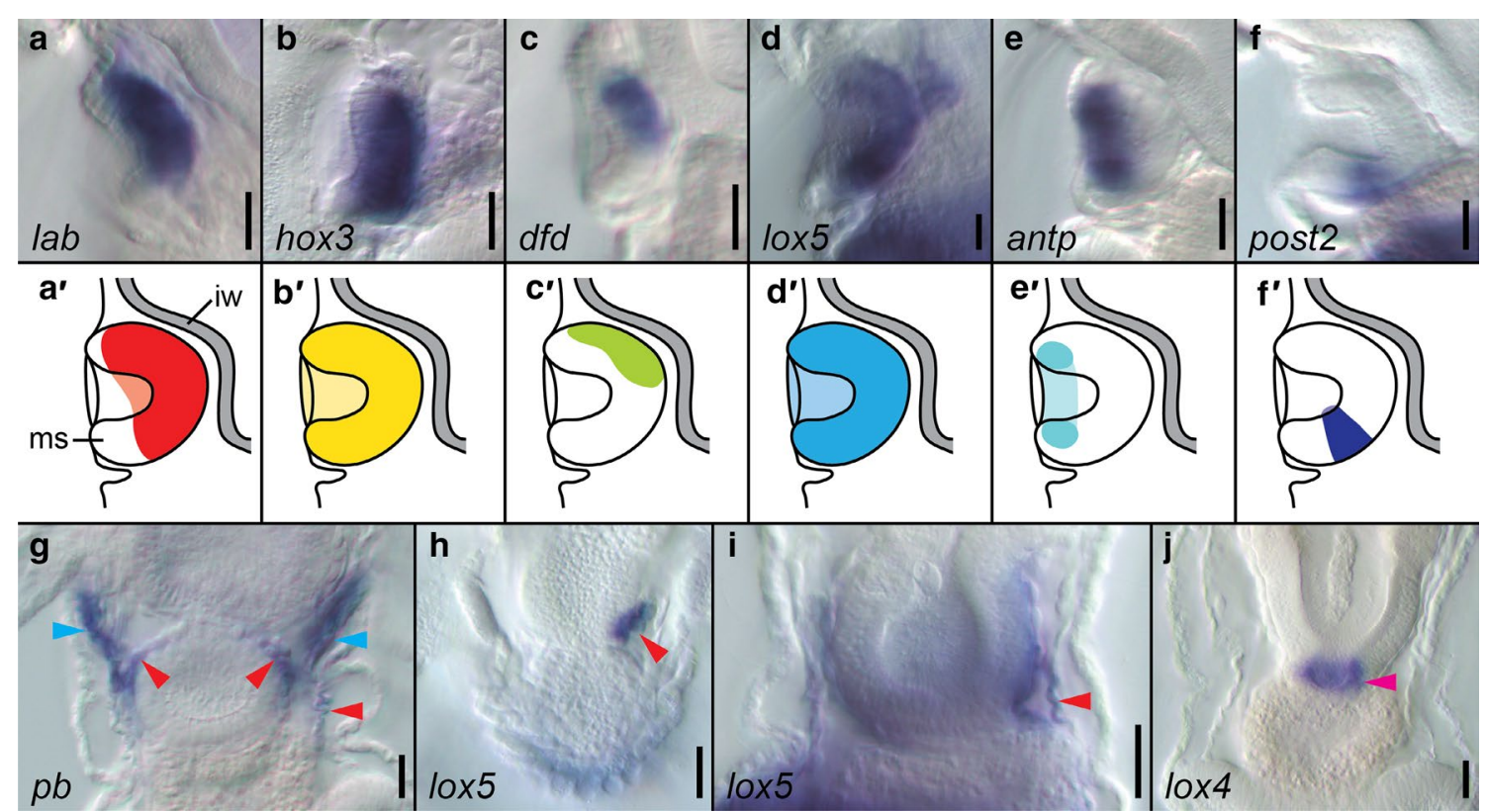

Fig. 5 Details of the expression of some of the Hox genes in the actinotrocha larvae of Phoronopsis harmeri. Expression of the Hox genes in the metasomal sac of 8-tentacle actinotrochae $(\mathbf{a}-\mathbf{f})$ and schematic interpretation of those expression patterns $\left(\mathbf{a}^{\prime}-\mathbf{f}^{\prime}\right)$. Expression of $p b$ in the 8-tentacle actinotrocha (g). Expression of lox5 in the left mesoderm of late 6 -tentacle (h) and 8-tentacle actinotrocha (i). Expression of lox4 in the digestive system of 8-tentacle actinotrocha (j). Scale bars $25 \mu \mathrm{m}$. ms metasomal sac, iw intestinal wall. Blue arrowheads indicate expression in the protonephridia, red arrowheads expression in the mesoderm and magenta arrowhead expression in the digestive system

(see "Methods" section for details), whose expression we managed to detect, foxGa, is expressed in the early larva in the epidermal cells, from which the tentacles will develop (Fig. 6a-c). In 8-tentacle stage the gene expression was not detected (data not shown). We managed to clone one of two foxQ2 paralogues, FoxQ2b, and detected its expression in the apical organ and the adjacent preoral coelom of both early and 8-tentacle stage larvae (Fig. $6 \mathrm{~d}-\mathrm{g}$ ). In the 8-tentacle stage the gene was additionally expressed in two endodermal rings-one in the anterior stomach and another at the border between stomach and midgut (Fig. 6f, g). six3/6 is expressed in the early larvae in the apical organ, hood mesoderm, preoral coelom, postoral ectoderm and in the stomach (Fig. 6h, i) as previously reported [85]. In 8-tentacle actinotrocha six3/6 is expressed in the apical organ, hood muscles, preoral coelom and some cells along ventral side of anterior digestive system (Fig. 6j-m). In early larvae otx is expressed in the apical organ, ventral preoral ectoderm, anterior portion of the digestive tract and in two spots in the ventro-posterior ectoderm, which lay in the prospective tentacular territory (Fig. $6 n-p$ ), following the expression pattern described before [85]. In the 8-tentacle stage, otx is expressed in the apical organ, rim of the oral hood, preoral coelom, anterior portion of the digestive tract and in the small spots close to the tips of each tentacle (Fig. 6q-u). pax4/6 is expressed in the early larvae in the two stripes of cells which extend along ventral side of the larva, from mouth to about half of the body length (Fig. $6 \mathrm{v}, \mathrm{w}$ ) and which correspond with the position to the tentacular neurite bundles [78]. In 8-tentacle stage pax4/6 expression is detected along frontal side of each larval tentacle (Fig. 6x, y), which also corresponds to the subset of tentacular innervation [78] and in the scattered neurons around the anterior digestive tract (Fig. 6y). In general the head-specific genes are broadly expressed in both developmental stages in the body structures anterior to the Hox-expressing territory (Fig. 6Z).

\section{Discussion}

\section{Hox gene complement in Phoronida}

Similar to the results of the investigation of $P$. australis genome, we identified eight Hox genes in Ph. harmeri, which represent single copies of the conserved orthologues of the spiralian Hox genes (Figs. 1c, 2). Luo et al. [89] reported that $P$. australis lacks $s c r$ and post 1 orthologues and we also did not identify orthologues of those two genes in the transcriptome of Ph. harmeri, strengthening the idea they were already absent in the common ancestor of all phoronids. 


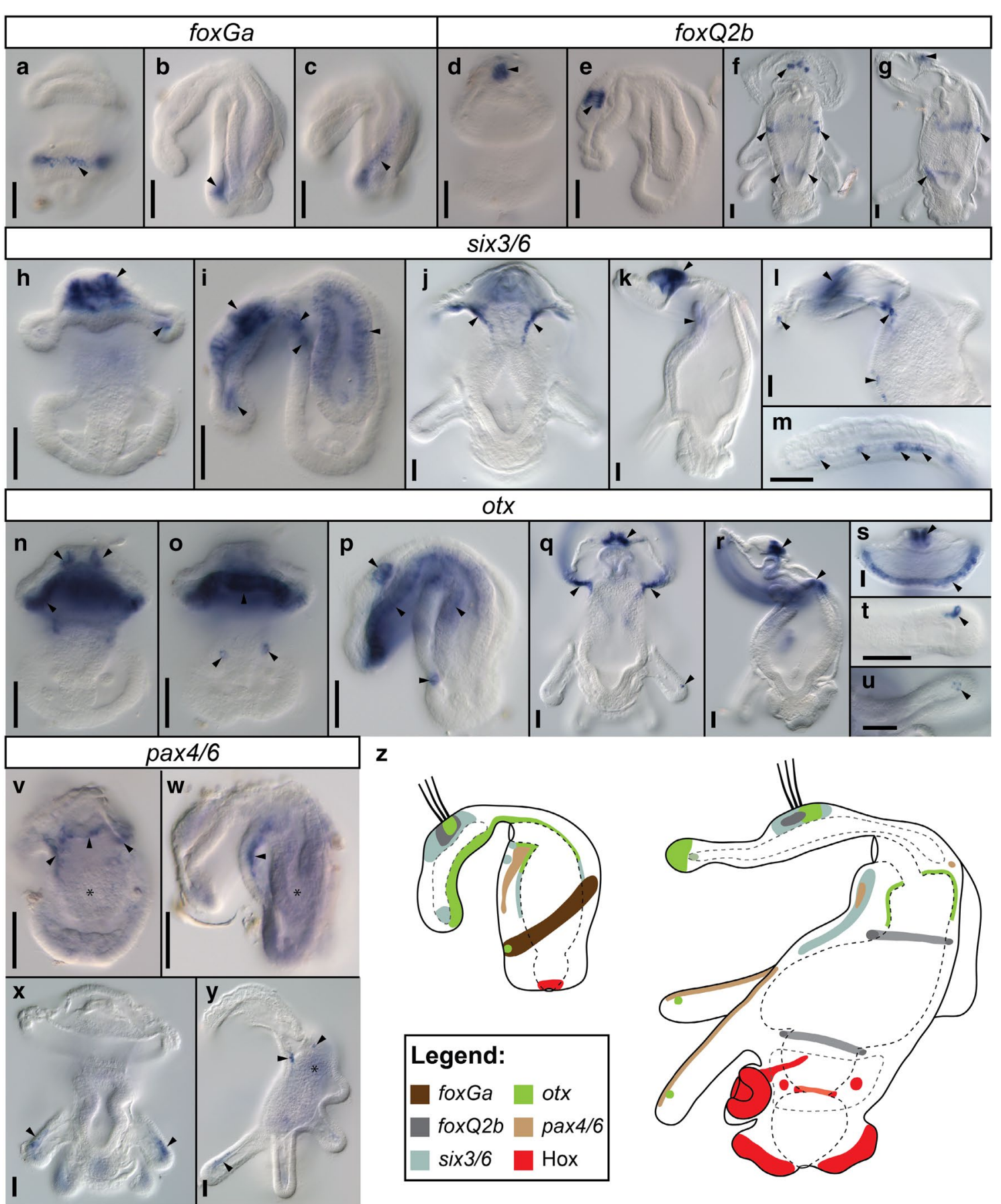

Fig. 6 Expression of head-specific genes in early larva $(\mathbf{a}-\mathbf{e}, \mathbf{h}, \mathbf{i}, \mathbf{n}-\mathbf{p}, \mathbf{v}, \mathbf{w})$ and 8-tentacle stage actinotrocha $(\mathbf{f}, \mathbf{g}, \mathbf{j}-\mathbf{m}, \mathbf{q}-\mathbf{u}, \mathbf{x}, \mathbf{y})$ of Phoronopsis harmeri and comparison of expression of head-specific and Hox genes in both larval stages $(\mathbf{z})$. For each panel the name of hybridized gene is shown in the white box above micrographs. Entire larvae in the dorso-ventral $(\mathbf{a}, \mathbf{d}, \mathbf{f}, \mathbf{h}, \mathbf{j}, \mathbf{n}, \mathbf{o}, \mathbf{q}, \mathbf{v}, \mathbf{x})$ and lateral $(\mathbf{b}, \mathbf{c}, \mathbf{e}, \mathbf{g}, \mathbf{i}, \mathbf{k}, \mathbf{p}, \mathbf{r}, \mathbf{w}, \mathbf{y})$ views. Details of expression in 8-tentacle stage larvae in oral hood and anterior body region (I), hood musculature (m), apical organ, preoral coelom and rim of the hood (s) and tips of the tentacles $(\mathbf{t}, \mathbf{u})$. Black arrowheads point to the particular expression domains (see text for details), while asterisks indicate unspecific background staining. Scalebars $25 \mu \mathrm{m}$ 
In their paper Luo et al. [89] suggested that scr, which is expressed in the shell forming tissues of brachiopods $[16,40]$, might be lost in Phoronida due to the evolutionary reduction of the shell in this clade. Such interpretation is in accordance with paleontological data, as a fossil cambrian tommotiid, Eccentrotheca sp., which has been proposed as a stem group phoronid [98, 99], possessed a mineralized external tube-shaped skeleton. Recent studies favor a sister group relationship between phoronids and ectoprocts $[52-55,100]$, the latter of which possess a mineralized external skeleton, similar to brachiopods. However, the Hox gene survey using degenerate polymerase chain reaction primers in the ectoproct Crisularia (Bugula) turrita did not retrieve a scr sequence [101], which questions the possible correlation between loss of this gene and the reduction of shell secreting tissues in phoronid lineage. Yet, since it is difficult to recover the full hox complement with degenerate polymerase chain reaction, further studies on bryozoan hox genes, utilizing genomic or transcriptomic data, are needed to ascertain whether $s c r$ is truly missing.

The gene that was identified as lox2 by Luo et al. [89] in the genome of $P$. australis (and its orthologue in Ph. harmeri) was recovered in our gene orthology analysis as orthologue of antp (Fig. 2). Inspection of the phylogenetic tree available in Luo et al. shows that the assessment of the orthology of this gene was tentative, since the gene was actually placed outside of the well-defined clade of lox2 in their analysis [89]. Identification of this gene as antp instead of lox2 is further supported by its position in the genome of $P$. australis, which corresponds to the antp position in the spiralian species with conserved, organized Hox clusters (Fig. 1c). Additionally, alignment of those phoronid genes with antp and lox2 shows that they lack typical signatures of lox2 [92] and instead are more similar to the antp sequence (Additional file 1: Fig. S1). Consequently, both phoronid species lack an orthologue of lox2, an absence, which is apparently shared by Phoronida with other Lophophorata [16, 89, $90,101]$ as well as with some other Spiralia-i.e. Rotifera [34, 102] and Platyhelminthes [42, 103]. Lox2 was originally described from leeches $[104,105]$ and later proposed as an evolutionary innovation of Lophotrochozoa ([92], sensu =Spiralia [106]). However, its orthologues are so far identified only in annelids (e.g. [27, 46, 92, 104, 105, 107, 108]), nemerteans [89], molluscs (e.g. $[30,36,41,92,107,109-112])$ and possibly kamptozoans [113] (however, in the latter the lox2-like sequence lacks most of the residues considered as lox2 signature; Additional file 1: Fig. S1). This indicates that lox2 evolved only after split of the common ancestor of those clades from remaining Spiralia and does not belong to the ancestral hox complement of all Spiralia [16]. Whether the absence of lox2 in lophophorates is plesiomorphic or represents an evolutionary reversal depends on the position of Lophophorata within Spiralia, which is still debatable and not fully resolved $[52-55,100]$.

\section{Hox genes in Phoronida do not show traces of collinear expression}

When assuming the presence of a similar gene order in the Hox cluster of Ph. harmeri as in P. australis then the former does not show any traces of temporally or spatially collinear expression of Hox genes (Fig. 4). This is in stark contrast to other Spiralia, in which at least some of the Hox genes show staggered expression along A-P axis (e.g. [16, 23, 27, 31, 35-37, 39, 41, 45]). The lack of collinear Hox expression in phoronids is especially intriguing taking into account that $P$. australis has highly organized Hox cluster and collinear expression (especially in its temporal aspect) has been proposed as a main evolutionary factor responsible for conservation of Hox cluster organization [9, 11-16, 49]. Therefore, either another mechanism is responsible for Hox cluster conservation in Phoronida or the two discussed phoronid species vary greatly in the cluster organization and/or Hox gene expression patterns.

Six out of eight identified Hox genes are expressed in the metasomal sac ( $p b$ and lox 4 being the only two, whose expression was not detected in the structure) and already at the stage of 8-tentacle actinotrocha some of those genes (lab, $d f d$, antp, post 2$)$ show differentiated expression in a particular region of the sac (Fig. 5), although without any clear pattern along the future A-P axis. However, it is possible that in the competent larvae (at the 24-tentacle stage, when the metasomal sac is a fully formed, elongated structure $[81,82])$, the expression of particular Hox genes is restricted to the different regions of the trunk rudiment and shows some traces of staggered expression along the future A-P axis of the worm body. Hence, the future investigation of Hox expression in competent larvae and freshly metamorphosed juveniles can reveal spatial collinearity obliterated in the early stages of metasomal sac development or eventually confirm a lack of collinear Hox expression throughout entire development of phoronids.

\section{Germ layer-specific expression of Hox genes in Spiralia}

Although Hox genes in Bilateria are predominantly expressed in the ectoderm (including nervous system) and their ectodermal expression is often considered as an ancestral feature [14, 28, 34], in various spiralian species certain Hox genes are also expressed in mesoderm, endoderm and clade-specific structures like chaetal sacs or shell fields (e.g. [16, 23, 24, 27, 29, 31, 35, 36, 39-41, 46]; Table 1). Inclusion of the data on 
Hox expression in Phoronida gives some new insight into the understanding of the evolution of germ layerspecific Hox expression in Spiralia. Ph. harmeri, similar to two investigated brachiopod species [16, 40], seems to lack expression of any of the Hox genes in the nervous system, a peculiarity that might actually represent an apomorphy of Lophophorata (Table 1). Three of the Hox genes-pb, hox3 and $d f d$-were shown to be differentially expressed along the A-P axis in the mesoderm of brachiopod larvae [16]. Out of those three genes, only $p b$ (which mesodermal expression is actually lacking in craniiformean Novocrania anomala [16]) is expressed mesodermally in Ph. harmeri, indicating that cooption of hox3 and $d f d$ into mesoderm patterning occurred after the split of brachiopods and phoronids. Comparison of Hox gene expression across Spiralia (Table 1) allows the observation that $p b$ is mesodermally expressed in many species and it is likely that mesodermal expression of $p b$ represents an ancestral condition in Lophotrochozoa (sensu stricto [106]). On the other hand, the expression of lox4 in the digestive system of Ph. harmeri is a peculiar and derived feature as this gene is expressed in other Spiralia in ectoderm, nervous system or mesoderm. In general, among investigated Spiralia, the Hox genes are rarely expressed in the digestive system (Table 1).
Hox gene expression and the nature of actinotrocha larvae We showed that in Ph. harmeri Hox genes are not expressed during embryogenesis, when the larval body is formed, but instead they are expressed mainly in prospective adult structures, namely in the metasomal sac (which will contribute to the adult trunk epidermis), posterior mesoderm (which contributes to the mesodermal structures in the adult trunk), the small posterior portion of the endoderm (which during metamorphosis descent into the trunk rudiment forming the loop of the U-shaped intestine) and the larval telotroch. In most of the investigated Bilateria, Hox genes are already expressed during early developmental stages and, if a biphasic life cycle is present, they are involved in the formation of both larval and adult body plans (e.g. [16, 27, $29-31,40,41,45,46,48])$. However, there are some animals that, similar to phoronids, deviate from this general pattern. Specifically, in pilidiophoran nemerteans [37] and indirectly developing hemichordates [38], the larvae develop without expressing any of the Hox genes, which instead patterns only the adult body rudiment.

Two evolutionary processes have been proposed to explain these observations. According to the first hypothesis, based on the results from pilidiophoran nemerteans, the new larval form, a pilidium, was intercalated into to the ancestral life cycle of gradually developing nemertean $[37,45]$. This intercalation of a larval form caused

Table 1 Expression of Hox genes in spiralian species

\begin{tabular}{|c|c|c|c|c|c|c|c|c|c|c|c|c|c|}
\hline \multirow[b]{2}{*}{ species } & \multirow[b]{2}{*}{ clade } & \multirow[b]{2}{*}{ reference } & \multicolumn{11}{|c|}{ Hox gene } \\
\hline & & & $l a b$ & $p b$ & hox3 & $d f d$ & $s c r$ & $10 \times 5$ & antp & lox 4 & lox2 & post2 & post1 \\
\hline $\begin{array}{l}\text { Phoronopsis } \\
\text { harmeri }\end{array}$ & Phoronida & this study & $\begin{array}{l}\text { ectoderm, } \\
\text { mesoderm }\end{array}$ & $\begin{array}{l}\text { mesoderm, } \\
\text { nephridia }\end{array}$ & ectoderm & ectoderm & $\begin{array}{l}\text { gene } \\
\text { absent }\end{array}$ & $\begin{array}{l}\text { ectoderm, } \\
\text { mesoderm }\end{array}$ & ectoderm & intestine & $\begin{array}{l}\text { gene } \\
\text { absent }\end{array}$ & ectoderm & $\begin{array}{l}\text { gene } \\
\text { absent }\end{array}$ \\
\hline $\begin{array}{l}\text { Terebratalia } \\
\text { transversa }\end{array}$ & Brachiopoda & $(16,40)$ & chaetal sac & $\begin{array}{l}\text { ectoderm, } \\
\text { mesoderm }\end{array}$ & $\begin{array}{l}\text { ectoderm, } \\
\text { mesoderm }\end{array}$ & $\begin{array}{l}\text { ectoderm, } \\
\text { mesoderm }\end{array}$ & shell field & ectoderm & ectoderm & ectoderm & $\begin{array}{l}\text { gene } \\
\text { absent }\end{array}$ & ectoderm & chaetal sac \\
\hline $\begin{array}{l}\text { Novocrania } \\
\text { anomala }\end{array}$ & Brachiopoda & (16) & chaetal sac & ectoderm & $\begin{array}{l}\text { ectoderm, } \\
\text { mesoderm }\end{array}$ & $\begin{array}{l}\text { ectoderm, } \\
\text { mesoderm }\end{array}$ & shell field & ectoderm & ectoderm & unknown & $\begin{array}{l}\text { gene } \\
\text { absent }\end{array}$ & unknown & $\begin{array}{l}\text { gene } \\
\text { absent }\end{array}$ \\
\hline Capitella teleta & Annelida & (46) & $\begin{array}{l}\text { ectoderm, } \\
\text { nervous } \\
\text { system }\end{array}$ & $\begin{array}{l}\text { ectoderm, } \\
\text { nervous } \\
\text { system }\end{array}$ & $\begin{array}{l}\text { ectoderm, } \\
\text { nervous } \\
\text { system }\end{array}$ & $\begin{array}{l}\text { ectoderm, } \\
\text { nervous } \\
\text { system }\end{array}$ & $\begin{array}{l}\text { ectoderm, } \\
\text { nervous } \\
\text { system }\end{array}$ & $\begin{array}{l}\text { ectoderm, } \\
\text { nervous } \\
\text { system }\end{array}$ & $\begin{array}{l}\text { ectoderm, } \\
\text { nervous } \\
\text { system }\end{array}$ & $\begin{array}{l}\text { ectoderm, } \\
\text { nervous } \\
\text { system }\end{array}$ & $\begin{array}{l}\text { ectoderm, } \\
\text { nervous } \\
\text { system }\end{array}$ & $\begin{array}{l}\text { ectoderm, } \\
\text { nervous } \\
\text { system }\end{array}$ & chaetal sac \\
\hline Alitta virens & Annelida & $(27,31)$ & $\begin{array}{l}\text { ectoderm, } \\
\text { chaetal sac, } \\
\text { nervous } \\
\text { system }\end{array}$ & $\begin{array}{l}\text { ectoderm, } \\
\text { mesoderm }\end{array}$ & ectoderm & $\begin{array}{l}\text { ectoderm, } \\
\text { nervous } \\
\text { system }\end{array}$ & $\begin{array}{l}\text { ectoderm, } \\
\text { nervous } \\
\text { system }\end{array}$ & $\begin{array}{l}\text { ectoderm, } \\
\text { nervous } \\
\text { system }\end{array}$ & $\begin{array}{l}\text { ectoderm, } \\
\text { nervous } \\
\text { system }\end{array}$ & $\begin{array}{l}\text { ectoderm, } \\
\text { nervous } \\
\text { system, } \\
\text { mesoderm }\end{array}$ & $\begin{array}{l}\text { ectoderm, } \\
\text { nervous } \\
\text { system }\end{array}$ & $\begin{array}{l}\text { ectoderm, } \\
\text { nervous } \\
\text { system, } \\
\text { mesoderm, } \\
\text { endoderm }\end{array}$ & chaetal sac \\
\hline $\begin{array}{l}\text { Chaetopterus } \\
\text { variopedatus }\end{array}$ & Annelida & (23) & $\begin{array}{l}\text { ectoderm, } \\
\text { nervous } \\
\text { system }\end{array}$ & $\begin{array}{l}\text { ectoderm, } \\
\text { nervous } \\
\text { system, } \\
\text { mesoderm }\end{array}$ & $\begin{array}{l}\text { ectoderm, } \\
\text { nervous } \\
\text { system }\end{array}$ & $\begin{array}{l}\text { ectoderm, } \\
\text { nervous } \\
\text { system }\end{array}$ & $\begin{array}{l}\text { ectoderm, } \\
\text { nervous } \\
\text { system }\end{array}$ & unknown & unknown & unknown & unknown & unknown & unknown \\
\hline $\begin{array}{l}\text { Acanthochitona } \\
\text { crinita }\end{array}$ & Mollusca & $(35,36)$ & $\begin{array}{l}\text { ectoderm, } \\
\text { mesoderm }\end{array}$ & mesoderm & mesoderm & $\begin{array}{l}\text { ectoderm, } \\
\text { mesoderm }\end{array}$ & mesoderm & $\begin{array}{l}\text { ectoderm, } \\
\text { mesoderm }\end{array}$ & mesoderm & $\begin{array}{l}\text { ectoderm, } \\
\text { mesoderm }\end{array}$ & mesoderm & $\begin{array}{l}\text { ectoderm, } \\
\text { mesoderm }\end{array}$ & $\begin{array}{l}\text { gene } \\
\text { absent }\end{array}$ \\
\hline Antalis entalis & Mollusca & (39) & $\begin{array}{l}\text { shell field, } \\
\text { nervous } \\
\text { system }\end{array}$ & $\begin{array}{l}\text { ectoderm, } \\
\text { nervous } \\
\text { system }\end{array}$ & $\begin{array}{l}\text { ectoderm, } \\
\text { shell field, } \\
\text { nervous } \\
\text { system, } \\
\text { mesoderm }\end{array}$ & $\begin{array}{l}\text { nervous } \\
\text { system, } \\
\text { mesoderm }\end{array}$ & $\begin{array}{l}\text { nervous } \\
\text { system, } \\
\text { mesoderm }\end{array}$ & $\begin{array}{l}\text { ectoderm, } \\
\text { nervous } \\
\text { system }\end{array}$ & $\begin{array}{l}\text { gene } \\
\text { absent }\end{array}$ & $\begin{array}{l}\text { ectoderm, } \\
\text { nervous } \\
\text { system, } \\
\text { mesoderm }\end{array}$ & unknown & $\begin{array}{l}\text { ectoderm, } \\
\text { nervous } \\
\text { system }\end{array}$ & $\begin{array}{l}\text { ectoderm, } \\
\text { shell field, } \\
\text { nervous } \\
\text { system }\end{array}$ \\
\hline $\begin{array}{l}\text { Lottia } \\
\text { goschimai }\end{array}$ & Mollusca & (41) & $\begin{array}{l}\text { shell field, } \\
\text { nervous } \\
\text { system }\end{array}$ & $\begin{array}{l}\text { shell field, } \\
\text { nervous } \\
\text { system }\end{array}$ & $\begin{array}{l}\text { shell field, } \\
\text { nervous } \\
\text { system }\end{array}$ & $\begin{array}{l}\text { shell field, } \\
\text { nervous } \\
\text { system }\end{array}$ & $\begin{array}{l}\text { shell field, } \\
\text { nervous } \\
\text { system }\end{array}$ & $\begin{array}{l}\text { shell field, } \\
\text { nervous } \\
\text { system }\end{array}$ & $\begin{array}{l}\text { nervous } \\
\text { system }\end{array}$ & $\begin{array}{l}\text { shell field, } \\
\text { nervous } \\
\text { system }\end{array}$ & $\begin{array}{l}\text { ectoderm, } \\
\text { shell field, } \\
\text { nervous } \\
\text { system }\end{array}$ & $\begin{array}{l}\text { shell field, } \\
\text { nervous } \\
\text { system }\end{array}$ & $\begin{array}{l}\text { nervous } \\
\text { system }\end{array}$ \\
\hline $\begin{array}{l}\text { Brachionus } \\
\text { manjavacas }\end{array}$ & Rotifera & (34) & $\begin{array}{l}\text { gene } \\
\text { absent (?) }\end{array}$ & $\begin{array}{l}\text { nervous } \\
\text { system }\end{array}$ & $\begin{array}{l}\text { nervous } \\
\text { system }\end{array}$ & $\begin{array}{l}\begin{array}{l}\text { nervous } \\
\text { system }\end{array} \\
\text { sy }\end{array}$ & unknown & $\begin{array}{l}\text { nervous } \\
\text { system }\end{array}$ & $\begin{array}{l}\text { gene } \\
\text { absent (?) }\end{array}$ & $\begin{array}{l}\text { gene } \\
\text { absent (?) }\end{array}$ & $\begin{array}{l}\text { gene } \\
\text { absent (?) }\end{array}$ & $\begin{array}{l}\text { gene } \\
\text { absent (?) }\end{array}$ & $\begin{array}{l}\text { gene } \\
\text { absent (?) }\end{array}$ \\
\hline
\end{tabular}


Hox gene patterning to only be retained during development of the adult worm. In contrast the new larval form, in which the body axis is not aligned with the adult one, uses another molecular mechanism to provide primary positional information to the cells of the developing body $[37,45]$.

Another concept was proposed to explain the phenomenon observed during larval development of a hemichordate Schizocardium californicum [38, 91]. Although metamorphosis in this species is not so drastic [114] and the body axes of both stages are congruent, the larva develops without expression of any Hox genes. Instead, they are expressed only late during larval development and only in the most posterior region of the competent larvae, from which the trunk of the juvenile worm will develop during metamorphosis [38, 114]. Because the larva expresses genes that are usually expressed in the bilaterian head throughout its body, the so-called "head larva"-hypothesis was proposed which states that the larval body represents the homologue of only the head region of the future animal, while the trunk is added later during post-larval development [38]. It has been proposed that ancestrally in Bilateria Hox genes were involved only in the patterning of the trunk, while head developed from the anterior, Hox-free region, the condition, which is still retained in numerous bilaterian lineages [ $38,45,89,93,94]$. That would explain why tornaria, as a larva composed solely of the head, develops without expression of the Hox genes, which become activated only after the onset of trunk development and pattern only the adult body [38].

Both of those hypotheses (intercalation and "headlarva") might be applied to explain the Hox expression patterns we observed in Ph. harmeri. According to the first hypothesis, the specific actinotrocha larva would represent an evolutionary novelty in the life cycle of phoronids, which was intercalated in the phoronid lineage and that is why it is not patterned by an ancestral Hox gene system. Such an idea is supported by the fact, that the actinotrocha body plan does not bear obvious homology to those of any other spiralian larvae [80, 115-117]. Additionally, similar to the case of pilidium, most of the larval tissues are lost during the drastic metamorphosis event and the larval A-P axis is not aligned with the juvenile one [60,72, 77, 81, 82]. Moreover, the actinotrocha is lacking in $P$. ovalis [60], which is the sister species to all remaining phoronids [62-64], suggesting that the actinotrocha was not even present in the most recent ancestor of all Phoronida, but instead appeared after the split between $P$. ovalis and the remaining phoronids.

On the other hand, from the morphological point of view, the tentacles of actinotrocha larvae correspond, in case of Ph. harmeri, to the tentacles of the lophophore in the adult worm ([73, 82, 116]; Fig. 1b), and the adult lophophore exhibits the molecular signature of a bilaterian head [89]. As tentacles are positioned posteriorly in the early actinotrocha, one can conclude that on a morphological basis the early actinotrocha is mostly composed of the head region. Following such interpretation, all of the Hox genes are expressed in the structures that will contribute to the adult trunk tissues but are not expressed in the developing future head (and hence in the largest portion of the larval body). Accordingly, based on a body region specific transcriptome, it has been demonstrated that in adults of $P$. australis Hox genes are not expressed in the lophophore, while their expression is detectable in the trunk and posterior ampulla [89]. Similarly, in rhynchonelliformean and craniiformean brachiopods none of the Hox genes are expressed in the larval anterior lobe $[16,40]$, which contributes to the lophophore after metamorphosis [40, 116]. A lack of Hox expression in the adult lophophore tissue (as opposed to the remaining body regions) was also shown for the linguliformean Lingula anatina, based on the tissue-specific transcriptomics [89]. Additionally, our study shows that two of the Hox genes (lox5 and post2) are expressed in the telotroch, which represent a truly larval structure, that is lost during metamorphosis [73, 82], therefore Hox genes are indeed, albeit to only a limited degree, involved in larval development. Hox gene expression in the larval telotroch is a result of the telotroch representing a truly "posterior" structure, which belongs to the post-head body region even in the earliest, "head dominated" actinotrocha. The "head larva" interpretation is additionally strengthened by our results of the expression of several head-specific genes in $\mathrm{Ph}$. harmeri. Those genes are broadly expressed in the early larvae and 8-tentacle stage, but only in the structures located anteriorly to the Hoxexpressing territory (Fig. 6z), resembling conditions in developing tornaria [38].

\section{Conclusions}

Hox gene expression is activated late during the development of Ph. harmeri. The larval body develops without expressing any of the Hox genes, which instead are expressed in the tissues of the prospective rudiment of the adult worm and in the telotroch. Such expression might result either from the intercalation of actinotrocha larva into the ancestral life cycle of phoronids or from the fact that the early larva of phoronids represents a "head larva", which develops without expressing any Hox genes. Our investigation of head-specific genes expression profiles confirms that most of the larval body exhibits head-specific gene expression profile. Those two explanations are not mutually exclusive and we propose that actinotrocha was intercalated into the phoronid life cycle 
by precocious development of the anterior structures or by delayed development of the trunk rudiment in the ancestral phoronid larva. Such hypotheses can be tested by the investigation of the Hox gene expression during the development of Phoronis ovalis, a sister species to all remaining Phoronida, which lacks the actinotrocha larva stage and develops through a creeping, worm-like larva.

\section{Methods}

\section{Animal collection and fixation}

Gravid females of Ph. harmeri Pixell, 1912 were collected in Bodega Bay ( $38^{\circ} 18^{\prime} 51.9012^{\prime \prime} \mathrm{N} 123^{\circ} 3^{\prime} 12.3012^{\prime \prime} \mathrm{W}$ ) in California during April and May. Although the California population of Phoronopsis is sometimes referred to as separate species Ph. viridis [84, 118], we followed the widely accepted interpretation of Joan Rattenbury Marsden, that $P h$. viridis is in fact a younger synonym of Ph. harmeri [119]. The animals were opened in the laboratory and eggs (fertilized during dissection by sperm stored in the coelom of females) were transferred to the clean cultures with filtered see water (as described in, e.g. [78, 84, 85]). Embryos are initially lecithotrophic, but, after formation of the gut, larvae require feeding, hence concentrated Rhodomonas or Rhinomonas algae were added to the cultures. Water in the larval cultures was exchanged every 2-3 days, followed by the addition of fresh algae. Embryos and larvae on desired developmental stages were relaxed with $8 \% \mathrm{MgCl}_{2}$, fixed in $3.7 \%$ formaldehyde and subsequently washed in phosphate buffer with $0.1 \%$ Tween-20. Fixed animals were stored in $100 \%$ methanol in $-20^{\circ} \mathrm{C}$.

\section{Hox genes identification and orthology assessment}

We searched the transcriptome of Ph. harmeri with reciprocal TBLASTN using eight Hox protein sequences from Phoronis australis. The top ten homeodomain-containing BLAST hits from each search were blasted back against the protein database at NCBI (http://blast.ncbi. nlm.nih.gov/) and if any Hox gene was among top reciprocal hits, the sequence was considered to be a putative Hox gene. We identified eight sequences, which passed this reciprocal test and translated them to the protein sequences using CLC Main Workbench 7. Orthology of particular phoronid Hox genes was assessed based on the results of phylogenetic analysis. In order to construct the alignment, amino acid sequences of Hox transcription factors and nucleotide sequences of Hox genes from several spiralian species were obtained from GenBank (https ://www.ncbi.nlm.nih.gov/genbank/), the ENSEMBL genome data base (https://www.ensembl.org/index.html) and the website of Marine Genomics Unit of Okinawa Institute of Science and Technology (http://marin egenomics.oist.jp). For the nucleotide sequences, ORFs were determined based on BLAST results at NCBI and sequences were translated into proteins using CLC Main Workbench 7. All spiralian sequences used in this study with their source and accession number are provided in the Additional file 1: Table S1.

The spiralian Hox protein sequences, including putative Hox genes of Ph. harmeri, were aligned in CLC Main Workbench 7 and then the alignment was manually trimmed to contain the conserved homeodomain $(60$ amino acids), five aa $5^{\prime}$ of the homeodomain, and eight aa $3^{\prime}$ of the homeodomain (the trimmed alignment in FASTA format is available in the Additional file 1). Additionally, several spiralian $E v x$ sequences were added as an outgroup. ProtTest3 [120] was used to determine the best-fitting substitution model $(J T T+I+G)$. Bayesian analysis was run in MrBayes v3.2.6 [121, 122] with the JTT $+\mathrm{I}+\mathrm{G}$ substitution model in two independent runs, each with four Markov chains (three heated and one cold) with 3.000.000 generations sampled every 500 generations. The first $25 \%$ of samples were discarded as burn-in and the remaining trees were used to calculate posterior probability values and construct the consensus tree, which was visualized and adjusted in FigTree v1.4.3.

All new sequences obtained and identified in this study were uploaded to the GenBank (accession numbers MN443105-MN443114).

\section{Gene cloning and probe synthesis}

Fragments of each Hox gene were amplified from cDNA libraries from mixed larval and adult tissues using genespecific primers (provided in Additional file 1: Table S2) designed in MacVector 11.0.4 based on the sequences found in the transcriptome. PCR products were cloned into pGEM-T Easy vectors (Promega, USA) and then transformed into competent Escherichia coli cells. Plasmid DNA was isolated and sequenced in both forward and reverse directions using T7 and SP6 primers. Labeled antisense RNA probes were transcribed from linearized DNA using digoxigenin-11-UTP (Roche, USA) according to the manufacturer's instructions.

\section{Head-specific genes}

Additionally, we searched the transcriptome of $P h$. harmeri in order to identify head-specific genes-foxG, foxQ2 and pax6. We identified two potential paralogues of both foxG and foxQ2 and called them correspondingly foxGa, foxGb, fox $\mathrm{Q} 2 a$ and foxQ2b. The vertebrate genes pax4 and pax6 originated through the vertebratespecific duplication [123-125] and accordingly their protostome orthologue should be called pax4/6, same as in case of the other invertebrate Pax genes ( $\mathrm{pax3} / 7$, pax1/9 and pax2/5/8). Therefore, despite the fact that pax6 is often used to refer to this gene in other protostomes, 
we decided to name the identified gene pax4/6 in order to stress its co-orthology to both vertebrate genes [124]. We ran phylogenetic analyses to make sure that identified phoronid genes truly represent orthologues of the genes of interest. For Fox genes we aligned phoronid Fox sequences with a published alignment of Fox domains [97], while for Pax4/6 we assembled alignment from sequences available in GenBank (see Additional file 1 for alignments and list of used sequences). The alignments were trimmed in trimAl software [126] (using the gappyout option) and the phylogenetic trees were calculated with FastTree v2.1 [127] (using the LG amino acid substitution model). The obtained trees where visualized and adjusted in FigTree v1.4.3 and confirmed identity of all identified phoronid genes (Additional file 1: Figs. S3 and S4). Sequences of phoronid Fox genes and pax4/6 were deposited in GenBank (accession numbers MN734372MN734376). Probes against head-specific genes were synthesized in the same way as described for Hox genes (although we did not manage to clone foxQ2a). Additionally we used the same dig-labeled probes against otx and six3/6 as in Andrikou et al. [85] (see "Method" section in there for more details regarding orthology of those genes).

\section{In situ hybridization and light microscopy}

Single whole-mount in situ hybridization was performed following an established protocol [128] with proteinase $\mathrm{K}$ digestion time of $2 \mathrm{~min}$. Probes were hybridized at a concentration of $1 \mathrm{ng} / \mu \mathrm{l}$ at $67^{\circ} \mathrm{C}$ for approximately $72 \mathrm{~h}$, detected with anti-digoxigenin-AP antibody in 1:5000 concentration in blocking buffer and visualized with nitroblue tetrazolium chloride and 5-bromo-4-chloro3-indolyl phosphate. Embryos and larvae were mounted in 70\% glycerol and examined with Zeiss Axiocam HRc connected to a Zeiss Axioscope Ax10 using bright-field Nomarski optics.

\section{Image processing and figure preparation}

Light micrographs were adjusted in Adobe Photoshop CS6 for contrast and assembled in Adobe Illustrator CS6. All figures and drawings were prepared in Adobe Illustrator CS6.

\section{Supplementary information}

Supplementary information accompanies this paper at https://doi. org/10.1186/s13227-020-0148-z.

Additional file 1. Additional figures and tables.

\section{Acknowledgements}

We thank Yale Passamaneck, who contributed with phoronid collection and spawning. Chris Lowe from Hopkins Marine Station of Stanford University is greatly acknowledged for hosting LG in his lab in April-May 2018 and for sharing a transcriptome of $\mathrm{Ph}$. harmeri before it was made public. We also would like to thank Carmen Andrikou and Andrea Orús Alcalde as well as Chris Lowe and Paul Bump for contributing with animal collection in April-May 2018. Carmen Andrikou, Chris Lowe and Elena Temereva are additionally greatly acknowledged for reading and commenting on our manuscript, which helped us to improve some of our data interpretations. We also thank Nadya Rimskaya-Korsakova, who cloned and prepared the probe against pax4/6. Additionally, three anonymous reviewers are acknowledged for their valuable comments, which helped to improve our manuscript.

\section{Authors' contributions}

Both authors conceived the study, analyzed data and contributed to writing. LG took part in sample collection, conducted gene search and orthology assessments, performed in situ hybridization, arranged figures and drafted the manuscript. Both authors read and approved the final manuscript.

\section{Funding}

Research was supported by the European Research Council Community's Framework Program Horizon 2020 (2014-2020) ERC Grant Agreement 648861 and the Norwegian Research Council FRIPRO Grant 815194 to AH.

\section{Availability of data and materials}

Sequences generated and analyzed in this study have been deposited in NCBI's GenBank database under accession numbers MN443105-MN443114 and MN734372-MN734376. All remaining data generated or analyzed during this study are included in this published article or its additional materials.

\section{Ethics approval and consent to participate}

Studies of phoronids do not require ethics approval or consent to participate.

Consent for publication

Not applicable.

\section{Competing interests}

The authors declare that they have no competing interests.

\section{Author details}

${ }^{1}$ Sars International Centre for Marine Molecular Biology, University of Bergen, Thormøhlensgate 55, 5006 Bergen, Norway. ${ }^{2}$ Department of Biological Sciences, University of Bergen, Thormøhlensgate 55, 5006 Bergen, Norway.

Received: 26 November 2019 Accepted: 29 January 2020

Published online: 10 February 2020

References

1. Yanze N, Spring J, Schmidli C, Schmid V. Conservation of Hox/ParaHoxrelated genes in the early development of a cnidarian. Dev Biol. 2001;236(1):89-98.

2. Finnerty JR. Cnidarians reveal intermediate stages in the evolution of Hox clusters and axial complexity. Am Zool. 2001;41(3):608-20.

3. Ryan JF, Pang K, NISC Comparative Sequencing Program, Mullikin JC, Martindale MQ, Baxevanis AD. The homeodomain complement of the ctenophore Mnemiopsis leidyi suggests that Ctenophora and Porifera diverged prior to the ParaHoxozoa. Evodevo. 2010;1 (1):9.

4. He SN, del Viso F, Chen CY, Ikmi A, Kroesen AE, Gibson MC. An axial Hox code controls tissue segmentation and body patterning in Nematostella vectensis. Science. 2018;361(6409):1377.

5. McGinnis W, Krumlauf R. Homeobox genes and axial patterning. Cell. 1992:68(2):283-302.

6. Pearson JC, Lemons D, McGinnis W. Modulating Hox gene functions during animal body patterning. Nat Rev Genet. 2005;6(12):893-904.

7. Lemons D, McGinnis W. Genomic evolution of Hox gene clusters. Science. 2006;313(5795):1918-22.

8. Krumlauf R. Hox genes in vertebrate development. Cell. 1994;78(2):191-201.

9. Garcia-Fernàndez J. The genesis and evolution of homeobox gene clusters. Nat Rev Genet. 2005;6(12):881-92.

10. Mallo M, Wellik DM, Deschamps J. Hox genes and regional patterning of the vertebrate body plan. Dev Biol. 2010;344(1):7-15. 
11. Ferrier DEK, Minguillon C. Evolution of the Hox/ParaHox gene clusters. Int J Dev Biol. 2003;47(7-8):605-11.

12. Duboule D. The rise and fall of Hox gene clusters. Development 2007;134(14):2549-60.

13. Duboule D. Temporal colinearity and the phylotypic progression: a basis for the stability of a vertebrate Bauplan and the evolution of morphologies through heterochrony. Dev Suppl. 1994;1994:135-42.

14. Deutsch J, Le Guyader H. The neuronal zootype. An hypothesis. Cr Acad Ssci lll-Vie. 1998:321(9):713-9.

15. Monteiro AS, Ferrier DEK. Hox genes are not always Colinear. Int J Biol Sci. 2006;2(3):95-103.

16. Schiemann SM, Martín-Durán JM, Børve A, Vellutini BC, Passamaneck YJ, Hejnol A. Clustered brachiopod Hox genes are not expressed collinearly and are associated with lophotrochozoan novelties. Proc Natl Acad Sci USA. 2017;114(10):E1913-22.

17. Lewis EB. A gene complex controlling segmentation in Drosophila. Nature. 1978;276(5688):565-70.

18. Beeman RW. A homeotic gene-cluster in the red flour beetle. Nature. 1987;327(6119):247-9.

19. Graham A, Papalopulu N, Krumlauf R. The murine and drosophila homeobox gene complexes have common features of organization and expression. Cell. 1989;57(3):367-78.

20. Kenyon C, Wang B. A cluster of antennapedia-class homeobox genes in a nonsegmented animal. Science. 1991;253(5019):516-7.

21. Arenas-Mena C, Martinez P, Cameron RA, Davidson EH. Expression of the Hox gene complex in the indirect development of a sea urchin. Proc Natl Acad Sci USA. 1998;95(22):13062-7.

22. Arenas-Mena C, Cameron AR, Davidson EH. Spatial expression of Hox cluster genes in the ontogeny of a sea urchin. Development. 2000;127(21):4631-43.

23. Irvine SQ, Martindale MQ. Expression patterns of anterior Hox genes in the polychaete Chaetopterus: correlation with morphological boundaries. Dev Biol. 2000;217(2):333-51.

24. Hinman VF, O'Brien EK, Richards GS, Degnan BM. Expression of anterior Hox genes during larval development of the gastropod Haliotis asinina. Evol Dev. 2003;5(5):508-21.

25. Lee PN, Callaerts P, de Couet HG, Martindale MQ. Cephalopod Hox genes and the origin of morphological novelties. Nature. 2003:424(6952):1061-5.

26. Aronowicz J, Lowe CJ. Hox gene expression in the hemichordate Saccoglossus kowalevskii and the evolution of deuterostome nervous systems. Integr Comp Biol. 2006;46(6):890-901.

27. Kulakova M, Bakalenko N, Novikova E, Cook CE, Eliseeva E, Steinmetz $\mathrm{PRH}$, et al. Hox gene expression in larval development of the polychaetes Nereis virens and Platynereis dumerilii (Annelida, Lophotrochozoa). Dev Genes Evol. 2007;217(1):39-54

28. Hejnol A, Martindale MQ. Coordinated spatial and temporal expression of Hox genes during embryogenesis in the acoel Convolutriloba longifissura. BMC Biol. 2009:7:65.

29. Samadi L, Steiner G. Involvement of Hox genes in shell morphogenesis in the encapsulated development of a top shell gastropod (Gibbula varia L.). Dev Genes Evol. 2009;219(9-10):523-30.

30. Samadi L, Steiner G. Expression of Hox genes during the larval development of the snail, Gibbula varia (L.)-further evidence of non-colinearity in molluscs. Dev Genes Evol. 2010;220(5-6):161-72.

31. Bakalenko NI, Novikova EL, Nesterenko AY, Kulakova MA. Hox gene expression during postlarval development of the polychaete Alitta virens. Evodevo. 2013:4:13.

32. Janssen R, Eriksson BJ, Tait NN, Budd GE. Onychophoran Hox genes and the evolution of arthropod Hox gene expression. Front Zool. 2014;11:22.

33. Smith FW, Boothby TC, Giovannini I, Rebecchi L, Jockusch EL, Goldstein B. The compact body plan of tardigrades evolved by the loss of a large body region. Curr Biol. 2016;26(2):224-9.

34. Fröbius AC, Funch P. Rotiferan Hox genes give new insights into the evolution of metazoan bodyplans. Nat Commun. 2017:8:1.

35. Fritsch M, Wollesen T, de Oliveira AL, Wanninger A. Unexpected colinearity of Hox gene expression in an aculiferan mollusk. BMC Evol Biol. 2015;15:151.
36. Fritsch M, Wollesen T, Wanninger A. Hox and ParaHox gene expression in early body plan patterning of polyplacophoran mollusks. J Exp Zool Part B. 2016:326(2):89-104.

37. Hiebert LS, Maslakova SA. Hox genes pattern the anterior- posterior axis of the juvenile but not the larva in a maximally indirect developing invertebrate, Micrura alaskensis (Nemertea). BMC Biol. 2015;13:23.

38. Gonzalez P. Uhlinger KR, Lowe CJ. The adult body plan of indirect developing hemichordates develops by adding a Hox-patterned trunk to an anterior larval territory. Curr Biol. 2017:27(1):87-95.

39. Wollesen T, Monje SVR, de Oliveira AL, Wanninger A. Staggered Hox expression is more widespread among molluscs than previously appreciated. Proc Biol Sci. 1888;2018(285):20181513.

40. Gąsiorowski L, Hejnol A. Hox gene expression in postmetamorphic juveniles of the brachiopod Terebratalia transversa. EvoDevo. 2019;10:1.

41. Huan P, Wang Q, Tan S, Liu B. Dorsoventral decoupling of Hox gene expression underpins the diversification of molluscs. Proc Natl Acad Sci USA. 2019;117(1):503-12.

42. Currie KW, Brown DD, Zhu S, Xu C, Voisin V, Bader GD, et al. HOX gene complement and expression in the planarian Schmidtea mediterranea. EvoDevo. 2016:7:7.

43. Seo HC, Edvardsen RB, Maeland AD, Bjordal M, Jensen MF, Hansen A, et al. Hox cluster disintegration with persistent anteroposterior order of expression in Oikopleura dioica. Nature. 2004;431(7004):67-71.

44. Ikuta T, Yoshida N, Satoh N, Saiga H. Ciona intestinalis Hox gene cluster: its dispersed structure and residual colinear expression in development. Proc Natl Acad Sci USA. 2004;101(42):15118-23.

45. Hiebert LS, Maslakova SA. Expression of Hox, Cdx, and Six $3 / 6$ genes in the hoplonemertean Pantinonemertes californiensis offers insight into the evolution of maximally indirect development in the phylum Nemertea. EvoDevo. 2015;6:26.

46. Fröbius AC, Matus DQ Seaver EC. Genomic organization and expression demonstrate spatial and temporal Hox gene colinearity in the lophotrochozoan Capitella sp. I. PLoS ONE. 2008:3:12.

47. Mooi R, David B. Radial symmetry, the anterior/posterior axis, and echinoderm Hox genes. Annu Rev Ecol Evol Syst. 2008;39:43-62.

48. Pascual-Anaya J, Adachi N, Alvarez S, Kuratani S, D'Aniello S, GarciaFernandez J. Broken colinearity of the amphioxus Hox cluster. EvoDevo. 2012;3(1):28.

49. Pascual-Anaya J, Sato I, Sugahara F, Higuchi S, Paps J, Ren YD, et al. Hagfish and lamprey Hox genes reveal conservation of temporal colinearity in vertebrates. Nat Ecol Evol. 2018;2(5):859-66.

50. Emig C. Un nouvel embranchement: les Lophophorates. Bull Soc Zool France. 1977;102:341-4.

51. Emig C. On the origin of the Lophophorata. J Zool Syst Evol Res. 1984;22(2):91-4.

52. Laumer CE, Bekkouche N, Kerbl A, Goetz F, Neves RC, Sørensen MV, et al. Spiralian phylogeny informs the evolution of microscopic lineages. Curr Biol. 2015;25(15):2000-6.

53. Laumer CE, Fernandez R, Lemer S, Combosch D, Kocot KM, Riesgo A, et al. Revisiting metazoan phylogeny with genomic sampling of all phyla. Proc Biol Sci. 1906;2019(286):20190831.

54. Marlétaz F, Peijnenburg K, Goto T, Satoh N, Rokhsar DS. A new spiralian phylogeny places the enigmatic arrow worms among gnathiferans. Curr Biol. 2019;29(2):312-8.

55. Zverkov OA, Mikhailov KV, Isaev SV, Rusin LY, Popova OV, Logacheva MD, et al. Dicyemida and orthonectida: two stories of body plan simplification. Front Genet. 2019;10:443.

56. Halanych KM, Bacheller JD, Aguinaldo AMA, Liva SM, Hillis DM, Lake JA. Evidence from 18s ribosomal DNA that the lophophorates are protostome animals. Science. 1995;267(5204):1641-3.

57. Dunn CW, Hejnol A, Matus DQ, Pang K, Browne WE, Smith SA, et al. Broad phylogenomic sampling improves resolution of the animal tree of life. Nature. 2008;452(7188):745-U755.

58. Emig CC. Embryology of phoronida. Am Zool. 1977;17(1):21-37.

59. Santagata S. Phoronida. In: Wanninger A, editor. Evolutionary developmental biology of invertebrates 2. Berlin: Springer; 2015. p. 231-45.

60. Silén L. Developmental biology of Phoronidea of the Gullmar Fiord area (west coast of Sweden). Acta Zool. 1954;35(3):215-57.

61. Hermann K. Phoronida. In: Harrison FW, Woollacott RM, editors. Microscopic anatomy of invertebrates volume 13: Lophophorates, Entoprocta, and Cycliophora. New York: Wiley-Liss; 1997. p. 207-35. 
62. Temereva EN, Chichvarkhin A. A new phoronid species, Phoronis embryolabi, with a novel type of development, and consideration of phoronid taxonomy and DNA barcoding. Invertebr Syst. 2017;31(1):65-84.

63. Santagata S, Cohen BL. Phoronid phylogenetics (Brachiopoda; Phoronata): evidence from morphological cladistics, small and large subunit rDNA sequences, and mitochondrial cox1. Zool J Linn Soc. 2009;157(1):34-50.

64. Hirose M, Fukiage R, Katoh T, Kajihara H. Description and molecular phylogeny of a new species of Phoronis (Phoronida) from Japan, with a redescription of topotypes of P. ijimai Oka, 1897. Zookeys. 2014;398:1-31.

65. Nezlin LP. The development of monoaminergic elements of the nervous system in the actinotroch-planktonic larvae of Phoronopsis harmeri. Zh Evol Biokhim Fiziol. 1988;24(1):76-80.

66. Temereva EN, Tsitrin EB. Development and organization of the larval nervous system in Phoronopsis harmeri: new insights into phoronid phylogeny. Front Zool. 2014;11(3):1-25.

67. Bartolomaeus T. Ultrastructure and relationship between protonephridia and metanephridia in Phoronis muelleri (Phoronida). Zoomorphology. 1989;109(2):113-22.

68. Hayschmidt A. Catecholamine-containing, serotonin-Like, and FMRFamide-like immunoreactive neurons and processes in the nervous system of the early actinotroch larva of Phoronis vancouverensis (Phoronida)_distribution and development. Can J Zool. 1990;68(7):1525-36.

69. Hayschmidt A. Distribution of catecholamine-containing, serotoninlike and neuropeptide FMRFamide-like immunoreactive neurons and processes in the nervous system of the actinotroch larva of Phoronis muelleri (Phoronida). Cell Tissue Res. 1990;259(1):105-18.

70. Lacalli TC. Structure and organization of the nervous system in the actinotroch larva of Phoronis vancouverensis. Phil Trans R Soc Lond B. 1990;327(1244):655

71. Bartolomaeus T. Ultrastructure and formation of the body cavity lining in Phoronis muelleri (Phoronida, Lophophorata). Zoomorphology. 2001;120(3):135-48

72. Santagata S, Zimmer RL. Comparison of the neuromuscular systems among actinotroch larvae: systematic and evolutionary implications. Evol Dev. 2002;4(1):43-54

73. Santagata S. Structure and metamorphic remodeling of the larval nervous system and musculature of Phoronis pallida (Phoronida). Evol Dev. 2002;4(1):28-42

74. Santagata S. Larval development of Phoronis pallida (Phoronida): implications for morphological convergence and divergence among larval body plans. J Morphol. 2004;259(3):347-58.

75. Temereva EN, Malakhov VV. Development of excretory organs in Phoronopsis harmeri (Phoronida): from protonephridium to nephromixium. Zool Zh. 2006;85(8):915-24.

76. Temereva EN, Malakhov W. Embryogenesis and larval development of Phoronopsis harmeri Pixell, 1912 (Phoronida): dual origin of the coelomic mesoderm. Invertebr Reprod Dev. 2007;50(2):57-66.

77. Temereva EN. The digestive tract of actinotroch larvae (Lophotrochozoa, Phoronida): anatomy, ultrastructure, innervations, and some observations of metamorphosis. Can J Zool. 2010;88(12):1149-68.

78. Temereva $\mathrm{E}$, Wanninger A. Development of the nervous system in Phoronopsis harmeri (Lophotrochozoa, Phoronida) reveals both deuterostome- and trochozoan-like features. BMC Evol Biol. 2012;12:27.

79. Temereva EN, Malakhov W. Embryogenesis in phoronids. Invertebr Biol. 2012;9(1):1-39.

80. Temereva EN. Ventral Nerve Cord in Phoronopsis harmeri Larvae. J Exp Zool Part B. 2012;318B(1):26-34.

81. Temereva EN, Tsitrin EB. Development, organization, and remodeling of phoronid muscles from embryo to metamorphosis (Lophotrochozoa: phoronida). BMC Dev Biol. 2013;13:14.

82. Temereva EN, Malakhov W. Metamorphic remodeling of morphology and the body cavity in Phoronopsis harmeri (Lophotrochozoa, Phoronida): the evolution of the phoronid body plan and life cycle. BMC Evol Biol. 2015:15:229.

83. Temereva EN. Ground plan of the larval nervous system in phoronids: evidence from larvae of viviparous phoronid. Evol Dev. 2017;19(4):171-89.

84. Rattenbury JC. The embryology of Phoronopsis viridis. J Morphol. 1954:95(2):289-349.
85. Andrikou C, Passamaneck YJ, Lowe CJ, Martindale MQ, Hejnol A. Molecular patterning during the development of Phoronopsis harmeri reveals similarities to rhynchonelliform brachiopods. EvoDevo. 2019;10:33.

86. Pennerstorfer M, Scholtz G. Early cleavage in Phoronis muelleri (Phoronida) displays spiral features. Evol Dev. 2012;14(6):484-500.

87. Freeman $\mathrm{G}$. The bases for and timing of regional specification during larval development in Phoronis. Dev Biol. 1991:147(1):157-73.

88. Freeman G, Martindale MQ. The origin of mesoderm in phoronids. Dev Biol. 2002;252(2):301-11.

89. Luo YJ, Kanda M, Koyanagi R, Hisata K, Akiyama T, Sakamoto H, et al. Nemertean and phoronid genomes reveal lophotrochozoan evolution and the origin of bilaterian heads. Nat Ecol Evol. 2018;2(1):141-51.

90. Luo YJ, Takeuchi T, Koyanagi R, Yamada L, Kanda M, Khalturina M, et al. The Lingula genome provides insights into brachiopod evolution and the origin of phosphate biomineralization. Nat Commun. 2015;6:8301.

91. Hejnol A, Vellutini BC. Larval evolution: I'Il Tail You later. Curr Biol. 2017;27(1):R21-4

92. de Rosa R, Grenier JK, Andreeva T, Cook CE, Adoutte A, Akam M, et al. Hox genes in brachiopods and priapulids and protostome evolution. Nature. 1999:399(6738):772-6.

93. Lowe CJ, Wu M, Salic A, Evans L, Lander E, Stange-Thomann N, et al. Anteroposterior patterning in hemichordates and the origins of the chordate nervous system. Cell. 2003;113(7):853-65.

94. Steinmetz PRH, Urbach R, Posnien N, Eriksson J, Kostyuchenko RP, Brena $C_{\text {, et }}$ al. Six3 demarcates the anterior-most developing brain region in bilaterian animals. Evodevo. 2010;1:14

95. Santagata S, Resh C, Hejnol A, Martindale MQ, Passamaneck YJ. Development of the larval anterior neurogenic domains of Terebratalia transversa (Brachiopoda) provides insights into the diversification of larval apical organs and the spiralian nervous system. Evodevo. 2012;3:3.

96. Kumamoto T, Hanashima C. Evolutionary conservation and conversion of Foxg1 function in brain development. Dev Growth Differ. 2017:59(4):258-69.

97. Fritzenwanker JH, Gerhart J, Freeman RM, Lowe CJ. The Fox/Forkhead transcription factor family of the hemichordate Saccoglossus kowalevskii. Evodevo. 2014:5:17.

98. Skovsted CB, Brock GA, Paterson JR, Holmer LE, Budd GE. The scleritome of Eccentrotheca from the lower Cambrian of South Australia: lophophorate affinities and implications for tommotiid phylogeny. Geology. 2008;36(2):171-4.

99. Skovsted CB, Brock GA, Topper TP, Paterson JR, Holmer LE. Scleritome construction, biofacies, biostratigraphy and systematics of the tommotiid Eccentrotheca helenia sp. Nov. from the early Cambrian of South Australia. Palaeontology. 2011;54:253-86.

100. Bleidorn C. Recent progress in reconstructing lophotrochozoan (spiralian) phylogeny. Org Divers Evol. 2019;2019:1-10.

101. Passamaneck YJ, Halanych KM. Evidence from Hox genes that bryozoans are lophotrochozoans. Evol Dev. 2004;6(4):275-81.

102. Flot JF, Hespeels B, Li X, Noel B, Arkhipova I, Danchin EGJ, et al. Genomic evidence for ameiotic evolution in the bdelloid rotifer Adineta vaga. Nature. 2013;500(7463):453-7.

103. Wasik K, Gurtowski J, Zhou X, Ramos OM, Delás MJ, Battistoni G, et al. Genome and transcriptome of the regeneration-competent flatworm, Macrostomum lignano. Proc Natl Acad Sci USA. 2015;112(40):12462-7.

104. Wysocka-Diller JW, Aisemberg GO, Baumgarten M, Levine M, Macagno ER. Characterization of a Homolog of Bithorax-Complex Genes in the Leech Hirudo medicinalis. Nature. 1989;341(6244):760-3.

105. Nardellhaefliger D, Shankland M. Lox2, a putative leech segment identity gene, is expressed in the same segmental domain in different stem-cell lineages. Development. 1992;116(3):697.

106. Hejnol A. A twist in time-the evolution of spiral cleavage in the light of animal phylogeny. Integr Comp Biol. 2010;50(5):695-706.

107. Simakov O, Marlétaz F, Cho SJ, Edsinger-Gonzales E, Havlak P, Hellsten $U$, et al. Insights into bilaterian evolution from three spiralian genomes. Nature. 2013;493(7433):526-31.

108. Zwarycz AS, Nossa CW, Putnam NH, Ryan JF. Timing and scope of genomic expansion within annelida: evidence from Homeoboxes in the genome of the earthworm Eisenia fetida. Genome Biol Evol. 2016;8(1):271-81. 
109. Albertin CB, Simakov O, Mitros T, Wang ZY, Pungor JR, Edsinger-Gonzales $E$, et al. The octopus genome and the evolution of cephalopod neural and morphological novelties. Nature. 2015;524(7564):220.

110. Belcaid M, Casaburi G, McAnulty SJ, Schmidbaur H, Suria AM, Moriano-Gutierrez S, et al. Symbiotic organs shaped by distinct modes of genome evolution in cephalopods. Proc Natl Acad Sci USA. 2019;116(8):3030-5.

111. Zhang GF, Fang XD, Guo XM, Li L, Luo RB, Xu F, et al. The oyster genome reveals stress adaptation and complexity of shell formation. Nature. 2012;490(7418):49-54.

112. Barucca M, Olmo E, Canapa A. Hox and paraHox genes in bivalve molluscs. Gene. 2003;317(1-2):97-102.

113. Merkel JW, Lieb B. Novel and conserved features of the Hox cluster of Entoprocta (Kamptozoa). J Phylogenet Evol Biol. 2018;6(1):194.

114. Gonzalez P, Jiang JZ, Lowe CJ. The development and metamorphosis of the indirect developing acorn worm Schizocardium californicum (Enteropneusta: Spengelidae). Front Zool. 2018;15:26.

115. Haug JT. Why the term "larva" is ambiguous, or what makes a larva? Acta Zool. 2018;48:15-34.

116. Kuzmina TV, Malakhov W. Structure of the brachiopod lophophore. Paleontol J. 2007;41(5):520-36.

117. Freeman G. A developmental basis for the Cambrian radiation. Zool Sci (Tokyo). 2007;24(2):113-22.

118. Hilton W. Phoronidea from the coast of southern California. J Entomol Zool. 1930;22:33-5.

119. Marsden JR. Phoronidea from the Pacific coast of North America. Can J Zool. 1959:37(2):87-111.

120. Darriba D, Taboada GL, Doallo R, Posada D. ProtTest 3: fast selection of best-fit models of protein evolution. Bioinformatics. 2011;27(8):1164-5.
121. Huelsenbeck JP, Ronquist F. MRBAYES: Bayesian inference of phylogenetic trees. Bioinformatics. 2001;17(8):754-5.

122. Ronquist F, Huelsenbeck JP. MrBayes 3: Bayesian phylogenetic inference under mixed models. Bioinformatics. 2003;19(12):1572-4.

123. Balczarek KA, Lai ZC, Kumar S. Evolution and functional diversification of the paired box (Pax) DNA-binding domains. Mol Biol Evol. 1997;14(8):829-42.

124. Manousaki T, Feiner N, Begemann G, Meyer A, Kuraku S. Co-orthology of Pax4 and Pax6 to the fly eyeless gene: molecular phylogenetic, comparative genomic, and embryological analyses. Evol Dev. 2011;13(5):448-59.

125. Wang W, Zhong J, Wang YQ. Comparative genomic analysis reveals the evolutionary conservation of Pax gene family. Genes Genetic Syst. 2010;85(3):193-206

126. Capella-Gutierrez S, Silla-Martinez JM, Gabaldon T. trimAl: a tool for automated alignment trimming in large-scale phylogenetic analyses. Bioinformatics. 2009;25(15):1972-3.

127. Price MN, Dehal PS, Arkin AP. FastTree 2-approximately maximumlikelihood trees for large alignments. PLoS ONE. 2010;5(3):e9490.

128. Hejnol A. In situ protocol for embryos and juveniles of Convolutriloba longifissura. Protoc Exch. 2008;201:101-12.

\section{Publisher's Note}

Springer Nature remains neutral with regard to jurisdictional claims in published maps and institutional affiliations.
Ready to submit your research? Choose BMC and benefit from:

- fast, convenient online submission

- thorough peer review by experienced researchers in your field

- rapid publication on acceptance

- support for research data, including large and complex data types

- gold Open Access which fosters wider collaboration and increased citations

- maximum visibility for your research: over 100M website views per year

At BMC, research is always in progress.

Learn more biomedcentral.com/submissions 